\title{
Investigating the performance of a greenhouse gas observatory in Hefei, China
}

\author{
Wei Wang ${ }^{1}$, Yuan Tian ${ }^{1,2}$, Cheng Liu ${ }^{1,3,4}$, Youwen Sun ${ }^{1}$, Wenqing Liu ${ }^{1}$, Pinhua Xie ${ }^{1}$, Jianguo Liu ${ }^{1}$, Jin Xu ${ }^{1}$, \\ Isamu Morino $^{5}$, Voltaire A. Velazco ${ }^{6}$, David W. T. Griffith ${ }^{6}$, Justus Notholt ${ }^{7}$, and Thorsten Warneke ${ }^{7}$ \\ ${ }^{1}$ Key Laboratory of Environmental Optics and Technology, Anhui Institute of Optics and Fine Mechanics, \\ Chinese Academy of Sciences, Hefei, 230031, China \\ ${ }^{2}$ University of Chinese Academy of Sciences, Beijing, 10049, China \\ ${ }^{3}$ School of Earth and Space Sciences, University of Science and Technology of China, Hefei, 230026, China \\ ${ }^{4}$ Center for Excellence in Urban Atmospheric Environment, Institute of Urban Environment, Chinese Academy \\ of Sciences, Xiamen, 361021, China \\ ${ }^{5}$ Satellite Observation Center, National Institute for Environmental Studies, Tsukuba, 305-8506, Japan \\ ${ }^{6}$ School of Chemistry, University of Wollongong, Northfields Ave, Wollongong, NSW, 2522, Australia \\ ${ }^{7}$ University of Bremen, Institute of Environmental Physics, P.O. Box 330440, 28334 Bremen, Germany
}

Correspondence to: Cheng Liu (chliu81@ustc.edu.cn) and Youwen Sun (ywsun@aiofm.ac.cn)

Received: 13 September 2016 - Discussion started: 8 December 2016

Revised: 15 June 2017 - Accepted: 20 June 2017 - Published: 25 July 2017

\begin{abstract}
A ground-based high-resolution Fourier transform spectrometer (FTS) station has been established in Hefei, China to remotely measure $\mathrm{CO}_{2}, \mathrm{CO}$ and other greenhouse gases based on near-infrared solar absorption spectra. Total column measurements of atmospheric $\mathrm{CO}_{2}$ and $\mathrm{CO}$ were successfully obtained from July 2014 to April 2016. The spectra collected with an InSb detector in the first year were compared with those collected by an InGaAs detector from July 2015, demonstrating that InGaAs spectra have better signal-to-noise ratios and rms of spectral fitting residuals relative to InSb spectra. Consequently, the measurement precision of the retrieved $\mathrm{XCO}_{2}$ and $\mathrm{XCO}$ for InGaAs spectra is superior to InSb spectra, with about 0.04 and $0.09 \%$ for $\mathrm{XCO}_{2}$, and 1.07 and $2.00 \%$ for XCO within clear-sky days respectively. Daily and monthly averages of columnaveraged dry air mole fraction of $\mathrm{CO}_{2}$ show a clear seasonal cycle, while the daily and monthly averages of XCO displayed no seasonal variation. Also, we analysed the relationship of the anomalies of $\mathrm{XCO}$ and $\mathrm{XCO}_{2}$, found that the correlations are only observable for individual days, and the data under different prevailing wind conditions during the observations displayed weak correlation. The observations based on the high-resolution FTS were also compared with the temporally coinciding measurements taken with a low-resolution
\end{abstract}

solar FTS instrument, the EM27/SUN. Ratioing the daily averaged $\mathrm{XCO}_{2}$ of EM27 and FTS gives an overall calibration factor of $0.996 \pm 0.001$. We also compared ground-based observations from the Tsukuba TCCON station with our observations, the results showing that the variation in phase and seasonal amplitude of $\mathrm{XCO}_{2}$ are similar to our results, but the variation of $\mathrm{XCO}$ in Tsukuba is quite different from our data in Hefei. To further evaluate our retrieved data, we made use of satellite measurements. The direct comparison of our observations with the Greenhouse Gases Observing Satellite (GOSAT) data shows good agreement of daily median $\mathrm{XCO}_{2}$, with a bias of $-0.52 \mathrm{ppm}$ and standard deviation of $1.63 \mathrm{ppm}$. The correlation coefficient $\left(R^{2}\right)$ is 0.79 for daily median $\mathrm{XCO}_{2}$ between our FTS and GOSAT observations. Daily median Orbiting Carbon Observatory 2 (OCO-2) data produce a positive bias of $0.81 \mathrm{ppm}$ and standard deviation of 1.73 ppm relative to our ground-based data. Our daily median $\mathrm{XCO}_{2}$ also show strong correlation with OCO-2 data, with correlation coefficient $\left(R^{2}\right)$ of 0.83 . Although there were a limited number of data during the observations due to instrument downtime and adverse weather, the results confirm the suitability of the observatory for ground-based long-term measurements of greenhouse gases with high precision and 
accuracy, and fulfil the requirements of the Total Carbon Column Observing Network (TCCON).

\section{Introduction}

Global warming is an important issue facing humankind and is largely due to anthropogenic emissions of greenhouse gases. The most important anthropogenic greenhouse gas, carbon dioxide $\left(\mathrm{CO}_{2}\right)$ continues to increase at a rate of approximately $2.0 \pm 0.1 \mathrm{ppm} \mathrm{yr}^{-1}$ for 2002-2011 despite emission reduction efforts worldwide (IPCC, 2014). The primary sources of the increased atmospheric carbon dioxide are fossil fuel combustion and land-use change due to deforestation. At the present time, the two anthropogenic sources release more than $9 \mathrm{GtC} \mathrm{yr}^{-1}$ into the atmosphere (IPCC, 2014; Le Quéré et al., 2014). However, the knowledge of $\mathrm{CO}_{2}$ source and sink distributions is still uncertain. In order to predict future climate change and understand the carbon cycle, more measurements are needed to improve our understanding of the $\mathrm{CO}_{2}$ sources and sinks.

Atmospheric carbon monoxide (CO), an indirect greenhouse gas, is an ozone precursor and a major pollutant in the troposphere. The main sources for $\mathrm{CO}$ in the atmosphere are biomass burning, fossil fuel combustion and oxidation of methane and non-methane hydrocarbons (Clerbaux et al., 2008; Yin et al., 2015). The main sinks of CO in the troposphere are oxidation reaction with the hydroxyl radical $(\mathrm{OH})$. $\mathrm{CO}$ plays an important role in atmospheric chemistry because it has an important effect on the oxidizing capacity of the troposphere.

Many techniques and methods have been successfully utilized in surface in situ measurement of atmospheric $\mathrm{CO}_{2}$, $\mathrm{CO}, \mathrm{CH}_{4}$ and $\mathrm{N}_{2} \mathrm{O}$ (Newman et al., 2013; Sarangi et al., 2014; Vardag et al., 2014; WMO, 2014; Buchholz et al., 2016; Schibig et al., 2015). Although these in situ measurements made at surface sites show high accuracy and precision, their usefulness in determining the global strengths and distributions of source and sink for greenhouse gases is limited due to their sparse spatial coverage. One way to improve the spatial and temporal sampling of $\mathrm{CO}_{2}$ and other trace gases is to obtain column abundances from space-based instruments, for example, the Scanning Imaging Absorption Spectrometer for Atmospheric Cartography (SCIAMACHY) on board ENVISAT, the Thermal and Near-infrared Sensor for Carbon Observation Fourier transform spectrometer (TANSO-FTS) on board GOSAT and the spectrometers on board OCO-2 (Bovensmann et al., 1999, 2004; Crisp et al., 2004; Hamazaki et al., 2005; Kuze et al., 2009; Boesch et al., 2011; Frankenberg et al., 2015). The data derived from space have provided useful information which can be used to constrain the carbon cycle, but they still need to be validated and improved in sensitivity and resolution.
Ground-based high-resolution Fourier transform spectrometer (FTS) can accurately and precisely measure total columns of $\mathrm{CO}_{2}, \mathrm{CO}, \mathrm{CH}_{4}, \mathrm{~N}_{2} \mathrm{O}$ and other gases (Washenfelder et al., 2006; Deutscher et al., 2010; Wunch et al., 2011a; Dohe, 2013; Rokotyan et al., 2014; Wang et al., 2014). The TCCON is a network of ground-based FTSs dedicated to simultaneous retrieval of column-averaged abundances of atmospheric constituents, by recording direct solar spectra in the near-infrared region. In order to provide insights into the carbon cycle, the $\mathrm{CO}_{2}$ total column data resulting from the TCCON sites require a precision of better than $0.1 \%$ (Olsen and Randerson, 2004). It has been demonstrated that TCCON measurement can achieve high accuracy and precision; for example, the claimed accuracy and precision of column-averaged dry air mole fraction of $\mathrm{CO}_{2}$ is better than $0.25 \%$ ( $1 \mathrm{ppm}$ for $\mathrm{CO}_{2}$; Messerschmidt et al., 2011; Wunch et al., 2011a). In addition, the data from TCCON stations have been used to calibrate and validate measurements from space, and also play a role in the validation of atmospheric modelling studies (Morino et al., 2011; Reuter et al., 2011; Schneising et al., 2012; Guerlet et al., 2013; Dils et al., 2014; Lindqvist et al., 2015; Ohyama et al., 2015; Kulawik et al., 2016). However, the present limitation of the TCCON measurements is the sparseness of their spatial coverage for carbon cycle research and validation of satellite measurements, especially in the Asian continental region. So far no TCCON measurements from China have been reported.

In this paper a high-resolution FTS dedicated to nearcontinuous observation of solar spectra deployed in Hefei, China is described. At present the observation project at the Hefei site may be one of the few operations using highresolution FTS to sample solar spectra in China, so our measurements are very important for providing information for constraining regional sources and sinks. An additional research aim is to validate satellite data, such as GOSAT, in orbit since January 2009, OCO-2, in orbit since July 2014, and the Chinese Carbon Dioxide Observation Satellite (TANSAT) launched in late 2016. In this paper, we investigate the potential of ground-based FTS to accurately and precisely determine temporal variability of atmospheric $\mathrm{CO}_{2}$ and $\mathrm{CO}$ at our measurement site in Hefei, China, and assess the ability of our observations to validate satellite data. Methane was also retrieved from the solar spectra and these results will be the subject of a separate publication (Tian et al., 2017).

\section{Measurement site and instrumentation}

The Hefei site $\left(31^{\circ} 54^{\prime} \mathrm{N}, 117^{\circ} 10^{\prime} \mathrm{E}, 29 \mathrm{~m}\right.$ above sea level; $\mathrm{m}$ a.s.l.), adjacent to a lake in a flat terrain, is located in the north-western rural area of Hefei city in eastern China (Fig. 1). It is part of the Anhui Institute of Optics and Fine Mechanics, operated by Key Laboratory of Environmental Optics and Technology, Chinese Academy of Sciences. We 

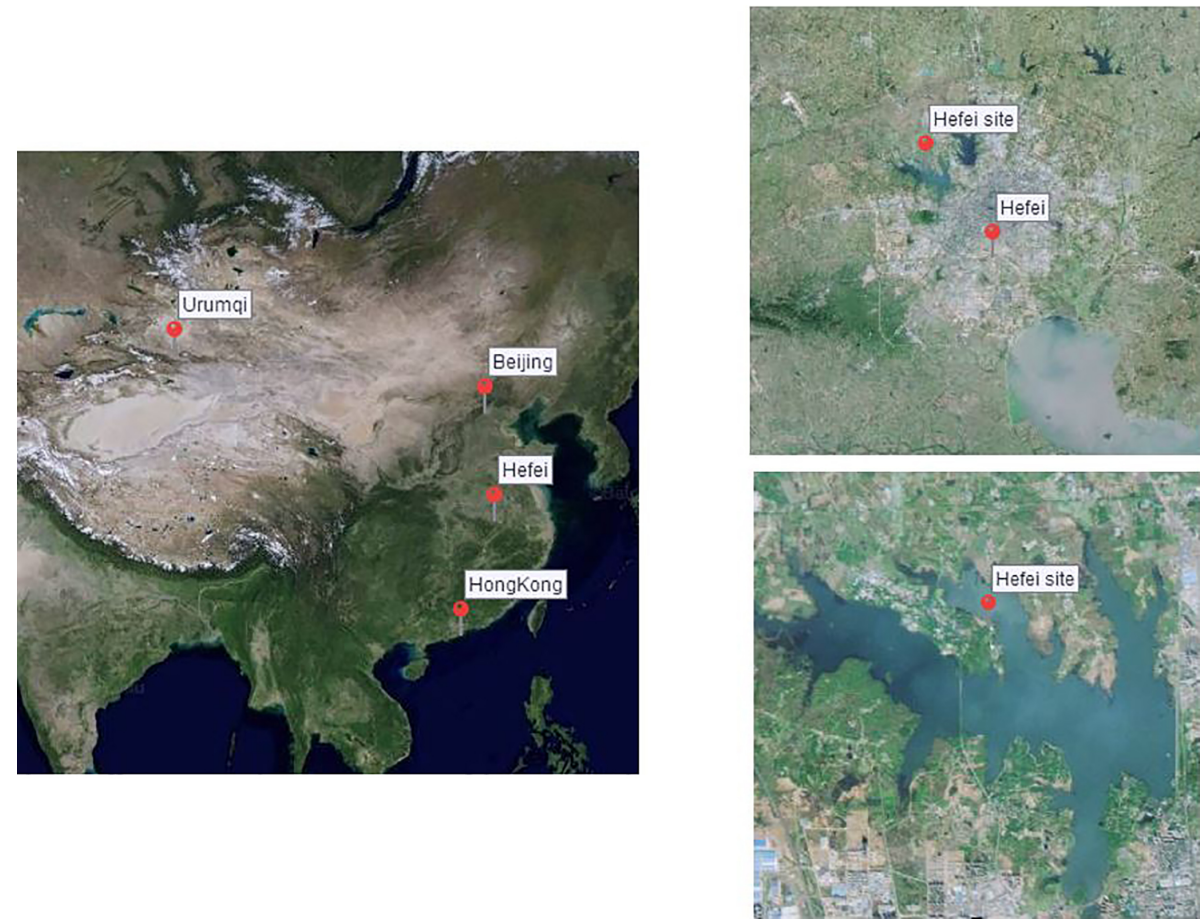

Figure 1. Map of China and location of the Hefei site.
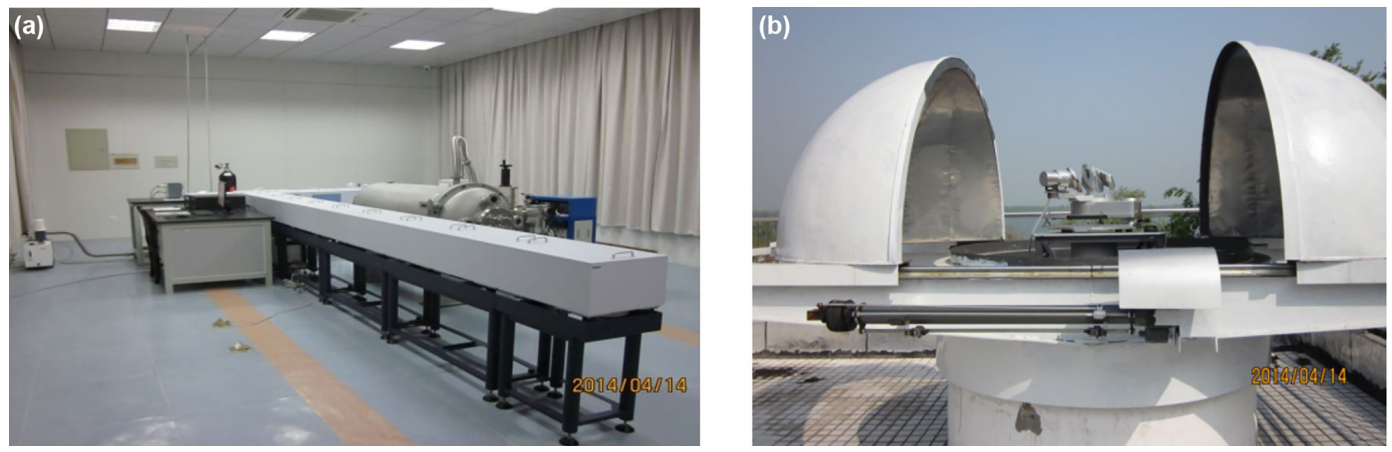

Figure 2. Bruker IFS 125HR spectrometer (a) and solar tracker (b).

installed the instrument, consisting of a Bruker IFS 125HR spectrometer and solar tracker, in January 2014. The Hefei site currently seeks to establish measurements according to TCCON measurement protocol, and we are making efforts to become a part of the TCCON network.

The FT spectrometer (IFS 125HR, Bruker Optics, Germany) has nine scanner compartments, with a maximum resolution of $0.00096 \mathrm{~cm}^{-1}$, as shown in Fig. 2. The solar tracker (A547, Bruker Optics, Germany) is mounted inside a motor-controlled dome $35 \mathrm{~m}$ a.s.1. on the roof of the laboratory building, and directs the solar beam into the spectrometer situated in the laboratory below. Tracking precision of $0.1^{\circ}$ can be achieved with the Camtracker mode. The spectrometer used a liquid-nitrogen-cooled InSb detector (1850$11000 \mathrm{~cm}^{-1}$ ) with a $\mathrm{CaF}_{2}$ beamsplitter to record solar spec- tra until the end of July 2015. A room-temperature InGaAs detector (3800-11000 cm $\mathrm{cm}^{-1}$ ) has been used since July 2015. A dichroic mirror will be installed to collect near-infrared (NIR) and mid-infrared (MIR) spectra simultaneously with InSb and InGaAs detectors with dual acquisition model, and this set-up is an extension of one of the standard TCCON set-up (Kiel et al., 2016a, b).

Additionally, a weather station (ZENO, Coastal Environmental Systems, USA) monitoring surface pressure, surface temperature, relative humidity, wind speed, wind direction, solar radiation, rain or snow and leaf wetness was mounted near the solar tracker on the roof in September 2015. At the same time pressure, temperature and relative humidity indoors are logged continuously. 
(a)

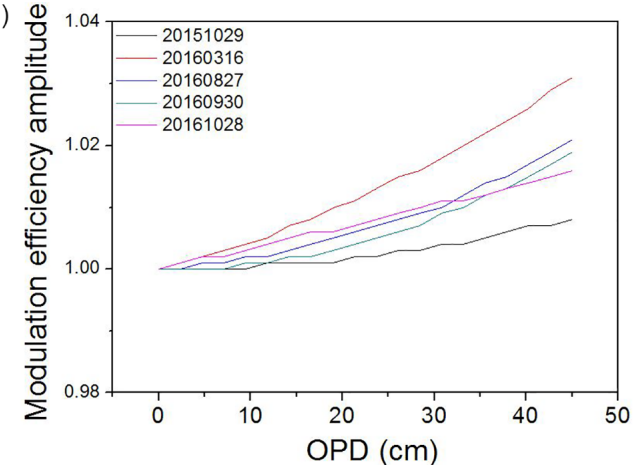

(b)

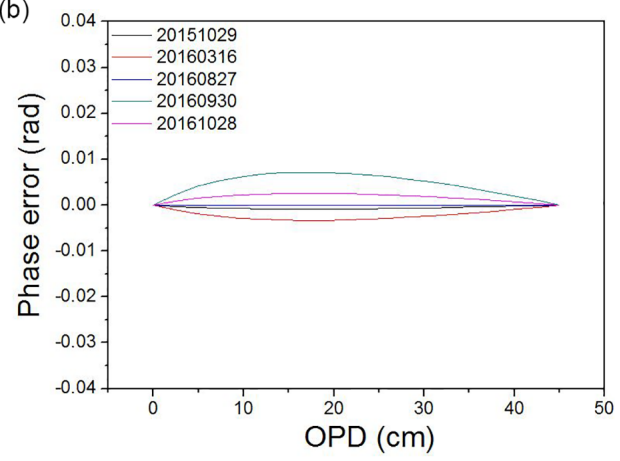

Figure 3. ME amplitudes (a) and phase errors (b) retrieved from $\mathrm{HCl}$ cell measurements.

\section{Instrumental line shape (ILS) monitoring}

Knowledge of the ILS is required to diagnose the alignment of the spectrometer and hence to retrieve total columns of gases from measurements accurately (Hase et al., 1999, 2013). $\mathrm{HCl}$ cell measurements using a NIR lamp as source were carried out from October 2015 since two calibrated $\mathrm{HCl}$ cells provided by Caltech arrived at our site. The cell measurements are performed once a month except during the instrument mechanical failure or NIR source failure. The ILS retrievals are done using LINEFIT 14.5 (Hase et al., 1999). The modulation efficiency (ME) amplitudes and phase errors are shown in Fig. 3. The average loss in ME amplitude at $45 \mathrm{~cm}$ optical path difference is $1.9 \pm 0.8 \%$, and the phase errors are lower than $0.01 \mathrm{rad}$. The ILS results show the alignment and stability of the instrument over the whole period.

\section{Data processing and analysis}

A spectral resolution of $0.02 \mathrm{~cm}^{-1}$ is employed with the maximum optical path difference of $45 \mathrm{~cm}$ to record the interferograms. Two successive scans (forward-backward) are collected with an acquisition time of approximately $90 \mathrm{~s}$. These forward and backward scans are processed separately. Figure 4 illustrates typical solar spectra collected by the InSb and InGaAs detectors. The signal-to-noise ratio of typical InSb spectra compared with InGaAs spectra is summarized in Sect. 5.1.

The GFIT retrieval fitting algorithm, which has been commonly used in TCCON, is used to analyse the spectra recorded by the FTS. GFIT is a non-linear least-squares fitting algorithm, developed as a spectral analysis tool for FTS spectra (Wunch et al., 2011a, 2015). The atmospheric forward model is used to calculate synthetic transmittance spectra from molecular absorption coefficients, atmospheric ray paths, a priori vertical profiles for temperature, pressure and water vapour from National Centers for Environmental Prediction/National Center for Atmospheric Research (NCEP/NCAR) reanalysis, and a priori vertical profiles for each trace gas. Then an inverse method compares the calculated spectra with the measured spectra, and iteratively scales the gas vertical profiles to minimize the root mean square of fitting residual. The fitting residual is defined as follows (Yang et al., 2002, 2005; Rokotyan et al., 2015):

$\chi^{2}=\sum_{i=1}^{N_{M}} \frac{\left(y_{i}^{\mathrm{M}}-y_{i}^{\mathrm{C}}\left(\alpha, \beta, v_{i}+\delta, \gamma_{1} x_{1}, \ldots \gamma_{n} x_{n}\right)\right)^{2}}{\sigma_{i}^{2}}$,

where $y_{i}^{\mathrm{M}}$ is the measured spectrum, $y_{i}^{\mathrm{C}}$ is the calculated spectrum, $v_{i}$ is the frequency in the $i$ th spectral channel, $\delta$ is the frequency shift of the measured spectrum, $\alpha$ and $\beta$ are the continuum level and tilt, $\gamma_{1}, \ldots, \gamma_{n}$ are scaling factors of target gases $x_{1}, \ldots, x_{n}, n$ is the number of fitted gases, $\sigma_{i}$ is the uncertainty of $y_{i}^{\mathrm{M}}$ and $N_{M}$ is the number of spectral channels.

The column abundance of a target gas is obtained from the scaled gas dry air mole fraction amounts from the best spectral fit. The derived column abundances of gases are converted to column-averaged dry air mole fraction (DMF), using the column abundance of $\mathrm{O}_{2}$ as a reference:

$X_{\mathrm{gas}}=0.2095 \times \frac{\text { column }_{\mathrm{gas}}}{\text { column }_{\mathrm{O}_{2}}}$,

where column $n_{\text {gas }}$ and column $\mathrm{O}_{2}$ are the column abundance of the target gas and $\mathrm{O}_{2}$ respectively, $X_{\text {gas }}$ is the calculated column-averaged DMF of the target gas. This procedure cancels some systematic errors, such as tracker pointing errors, which affect trace gases and $\mathrm{O}_{2}$ equally.

The spectral windows for retrieval of column $\mathrm{CO}_{2}, \mathrm{CO}$ and $\mathrm{O}_{2}$ are listed in Table 1 and are the standard GFIT windows. For $\mathrm{CO}_{2}$ and $\mathrm{CO}$, the retrieved column abundances from the two spectral windows were averaged and then converted into column-averaged DMF. We used GGG2014 to retrieve the columns of greenhouse gases. The TCCON calibration factors applied for $\mathrm{XCO}_{2}$ and $\mathrm{XCO}$ are 0.989 and 1.067 respectively (Wunch et al., 2010; Messerschmidt et al., 2011). For processing the data collected before installing the weather station (on 18 September 2015), we use meteorological pa- 

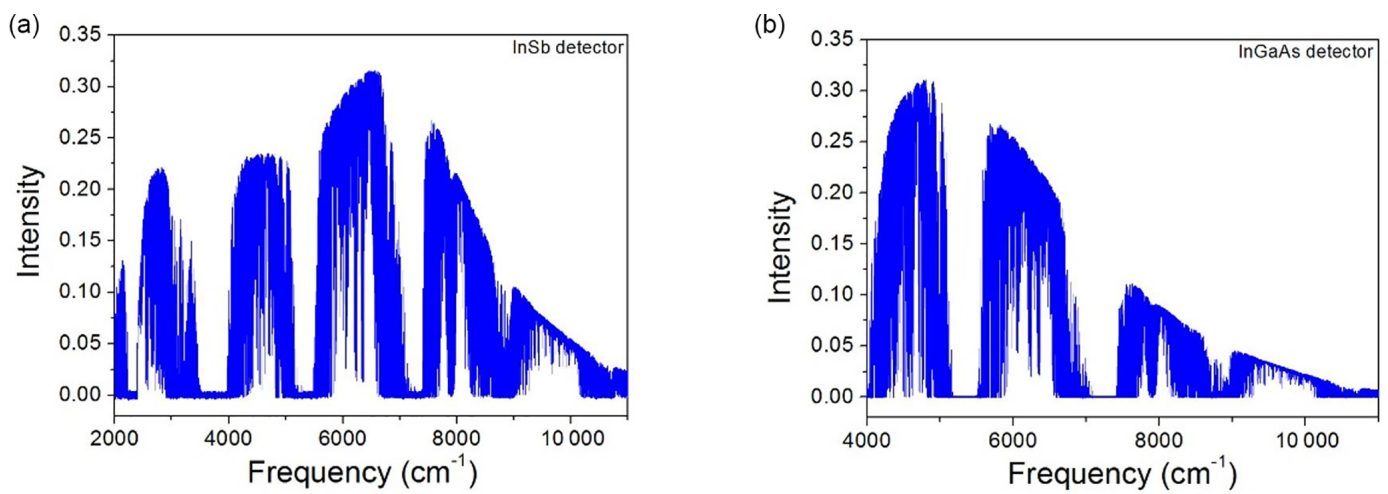

Figure 4. Typical solar spectra collected by an InSb detector on 24 October 2014 (a) and InGaAs detector on 4 August 2015 (b).

Table 1. Spectral windows for retrieval of column of $\mathrm{CO}_{2}, \mathrm{CO}$ and $\mathrm{O}_{2}$.

\begin{tabular}{lrrl}
\hline Gas & $\begin{array}{r}\text { Centre of spectral } \\
\text { window }\left(\mathrm{cm}^{-1}\right)\end{array}$ & $\begin{array}{r}\text { Width } \\
\left(\mathrm{cm}^{-1}\right)\end{array}$ & Interfering gas \\
\hline $\mathrm{CO}_{2}$ & 6220.0 & 80.0 & $\mathrm{H}_{2} \mathrm{O}, \mathrm{HDO}, \mathrm{CH}_{4}$ \\
$\mathrm{CO}_{2}$ & 6339.5 & 85.0 & $\mathrm{H}_{2} \mathrm{O}, \mathrm{HDO}$ \\
$\mathrm{CO}$ & 4233.0 & 48.6 & $\mathrm{CH}_{4}, \mathrm{H}_{2} \mathrm{O}, \mathrm{HDO}$ \\
$\mathrm{CO}$ & 4290.4 & 56.8 & $\mathrm{CH}_{4}, \mathrm{H}{ }_{2} \mathrm{O}, \mathrm{HDO}$ \\
$\mathrm{O}_{2}$ & 7885.0 & 240.0 & $\mathrm{H}_{2} \mathrm{O}, \mathrm{HF}, \mathrm{CO}_{2}$ \\
\hline
\end{tabular}

rameters from a weather station about $1 \mathrm{~km}$ away from our laboratory.

\section{Results and discussion}

\subsection{Comparison of InSb and InGaAs spectra}

The direct absorption spectra collected under clear-sky weather conditions from July 2014 to April 2016 are analysed here. Spectra from July 2014 to July 2015 were collected with the InSb detector, while the spectra were collected by the InGaAs detector from July 2015 to April 2016. Spectra with solar intensity variation during the scan of more than $5 \%$ are removed. The signal-to-noise ratio of a typical InGaAs spectrum compared with an InSb spectrum is summarized in Table 2. Signal-to-noise ratios of InGaAs spectra are 2-4 times higher than those of InSb spectra in the nearinfrared region.

It is also important to assess the spectral fitting. Figures 59 depict typical spectral fittings for InSb and InGaAs spectra. The measured spectra are shown in black, the fitted spectra in red and the residual in dark cyan. Figure 5 compares the typical spectral fittings of $\mathrm{CO}_{2}$ in the spectral window centred at $6220 \mathrm{~cm}^{-1}$. The rms spectral fitting residuals are about 0.32 and $0.19 \%$ for InSb and InGaAs spectra respectively. Figure 6 is a plot of typical spectral fittings of $\mathrm{CO}_{2}$ in the window centred at $6335 \mathrm{~cm}^{-1}$, showing the rms fitting residuals of 0.31 and $0.21 \%$ for $\mathrm{InSb}$ and InGaAs spectra. Figure 7 plots typical spectral fittings of $\mathrm{CO}$ in one spectral window centred at $4233 \mathrm{~cm}^{-1}$ using two detectors. The rms spectral fitting residuals are about 0.52 and $0.50 \%$ for InSb and InGaAs spectra. Figure 8 compares typical spectral fittings of $\mathrm{CO}$ in the other window centred at $4290 \mathrm{~cm}^{-1}$, with the rms error of fitting residuals about 0.54 and $0.46 \%$. Also, the typical spectral fittings of $\mathrm{O}_{2}$ in spectral regions between 7765 and $8005 \mathrm{~cm}^{-1}$ give 0.37 and $0.29 \% \mathrm{rms}$ for fitting residual, as plotted in Fig. 9. We conclude that all the rms errors of fitting residuals of InGaAs spectra are small relative to those of InSb spectra, as listed in Table 2.

Further, the measurement precision (repeatability) of the total columns are compared. The standard deviation of the retrieved column-averaged DMF from spectra sampled in $1 \mathrm{~h}$ around noon on a clear-sky day (cloud free) is calculated as a measure of precision. The data of 24 October 2014 and 4 August 2015 are used here. The measurement precisions of $X_{\text {gas }}$ for typical InGaAs spectra compared to InSb spectra are listed in Table 3. For both $\mathrm{CO}_{2}$ and $\mathrm{CO}$, the InGaAs precision is about two times better than the InSb precision.

Recent TCCON measurements have shown that the precision of the resulting mole fractions is about $0.15 \%$ for $\mathrm{CO}_{2}$ and $0.5 \%$ for CO (Toon et al., 2009; Messerschmidt et al., 2010; Wunch et al., 2010). Thus our results for $\mathrm{CO}_{2}$ are comparable to other TCCON stations, whereas the results of $\mathrm{CO}$ show poorer precision. From the comparison of SNR, rms error of fitting residuals and measurement precision for InGaAs and InSb spectra, it is preferable to use the InGaAs detector to collect the near-infrared solar spectra rather than the $\mathrm{InSb}$ detector.

\subsection{Variation of $\mathrm{XCO}_{2}$ and $\mathrm{XCO}$}

Time series of total column amounts of $\mathrm{CO}_{2}$ and $\mathrm{CO}$ from July 2014 to April 2016 are retrieved. The data are not continuous, with gaps due to instrument mechanical failure or adverse weather conditions, especially in February and March 2015. Figure 10 shows a time series of $X_{\text {air }}$ (the column- 
Table 2. The signal-to-noise ratio and spectral fitting of InGaAs spectra compared with InSb spectra for different spectral windows.

\begin{tabular}{lrrrrr}
\hline Gas & $\begin{array}{r}\text { Spectral } \\
\text { window }\left(\mathrm{cm}^{-1}\right)\end{array}$ & $\begin{array}{r}\text { SNR of } \\
\text { InGaAs }\end{array}$ & $\begin{array}{r}\text { SNR of } \\
\text { InSb }\end{array}$ & $\begin{array}{r}\text { rms } \\
\text { fitting } \\
\text { residual of } \\
\text { InGaAs }\end{array}$ & $\begin{array}{r}\text { rms } \\
\text { fitting } \\
\text { residual of } \\
\text { InSb }\end{array}$ \\
\hline $\mathrm{CO}_{2}$ & $6180-6260$ & 1050 & 320 & $0.19 \%$ & $0.32 \%$ \\
$\mathrm{CO}_{2}$ & $6297-6382$ & 997 & 320 & $0.21 \%$ & $0.31 \%$ \\
$\mathrm{CO}$ & $4208-4257$ & 1060 & 233 & $0.50 \%$ & $0.52 \%$ \\
$\mathrm{CO}$ & $4242-4318$ & 1170 & 240 & $0.46 \%$ & $0.54 \%$ \\
$\mathrm{O}_{2}$ & $7765-8005$ & 460 & 260 & $0.29 \%$ & $0.37 \%$ \\
\hline
\end{tabular}

(a)

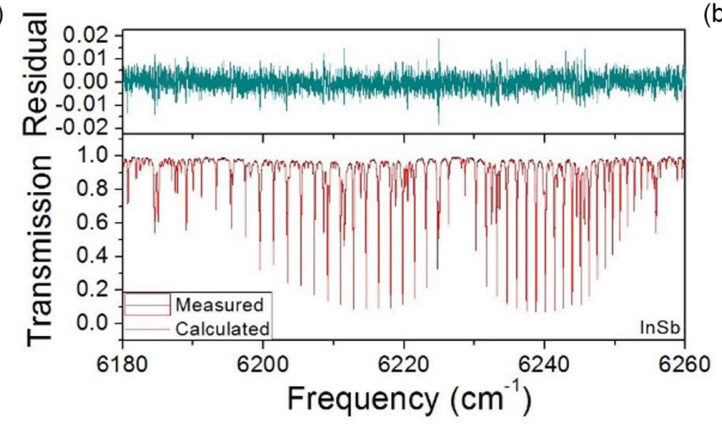

(b)

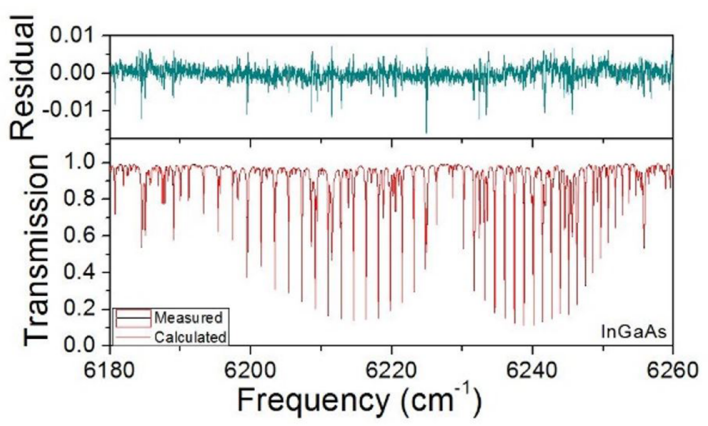

Figure 5. Spectral fitting of $\mathrm{CO}_{2}$ in spectral window of $6180-6260 \mathrm{~cm}^{-1}$ using an InSb detector (a) and InGaAs detector (b).

Table 3. The measurement precision of typical InGaAs spectra compared to InSb spectra for $\mathrm{XCO}_{2}$ and XCO.

\begin{tabular}{lrrr}
\hline Detectors & Mean & $\begin{array}{c}\text { Standard } \\
\text { deviation }\end{array}$ & Precision \\
\hline XCO $_{2}$ InGaAs & $398.17 \mathrm{ppm}$ & $0.17 \mathrm{ppm}$ & $0.04 \%$ \\
XCO $_{2}$ InSb & $397.15 \mathrm{ppm}$ & $0.34 \mathrm{ppm}$ & $0.09 \%$ \\
XCO_InGaAs & $87.79 \mathrm{ppb}$ & $0.94 \mathrm{ppb}$ & $1.07 \%$ \\
XCO_InSb & $94.85 \mathrm{ppb}$ & $1.86 \mathrm{ppb}$ & $2.00 \%$ \\
\hline
\end{tabular}

abundance of dry air in a ratio to that of $\mathrm{O}_{2}$ as in equation 2), with the value in the range between 0.96 and 1.02. The mean value is 0.98 with a standard deviation of $0.005(0.49 \%)$, consistent with other TCCON sites. Time series of individual measurements, daily averages and monthly averages of column-averaged DMF of $\mathrm{CO}_{2}$ are plotted in Fig. 11. The sampling days with a number of data points less than 10 are not considered due to a lack of representativeness. Figure 11 suggests that variation of $\mathrm{XCO}_{2}$ showed a clear seasonal cycle. $\mathrm{XCO}_{2}$ reaches a minimum in late summer, then slowly increases to the highest value in spring. The daily average of $\mathrm{XCO}_{2}$ ranges from $392.33 \pm 0.86$ to $411.62 \pm 0.90 \mathrm{ppm}$, and the monthly average value shows a seasonal amplitude of 8.31 and 13.56 ppm from 2014 to 2015 and from 2015 to 2016 respectively. The seasonal cycle is driven by biosphereatmosphere exchange. Photosynthesis results in the decrease of $\mathrm{CO}_{2}$ in the local growing season, whereas photosynthe- sis gradually ceases and $\mathrm{CO}_{2}$ builds up in winter and spring. However, the $\mathrm{XCO}_{2}$ measurements are sensitive to variations in exchange at the spatial scale of hundreds to thousands of kilometres; thus photosynthesis in the local growing season is not the only driver of the seasonal cycle. The site is influenced by regional anthropogenic emissions under the southeast wind directions, because it is about $10 \mathrm{~km}$ north-west of the Hefei urban area (population 7.7 million). Variations in $\mathrm{CO} / \mathrm{CO}_{2}$ with prevailing wind directions are used to discuss the influence of the regional anthropogenic emissions later in this section.

In the recent study of Wunch et al. (2011b), the ACOSGOSAT data and FTS observation in 2009-2010 indicated that $\mathrm{XCO}_{2}$ at the Japanese Tsukuba station had clear seasonal cycle, with a maximum in winter and a minimum in summer. In Butz et al. (2011), the observations from GOSAT and the co-located ground-based measurements captured the seasonal cycle of $\mathrm{XCO}_{2}$ with the late summer minimum and the spring maximum for four TCCON stations in the Northern Hemisphere. In the paper by Schneising et al. (2014), $\mathrm{XCO}_{2}$ determined by SCIAMACHY and CarbonTracker for the Northern Hemisphere (30 to $60^{\circ} \mathrm{N}$ ) based on monthly means exhibited distinct seasonal cycles, with peak-to-peak amplitude of $7.15 \pm 0.22$ and $6.27 \pm 0.21 \mathrm{ppm}$ respectively. Nguyen et al. (2014) showed that $\mathrm{XCO}_{2}$ estimated by CarbonTracker in the Northern Hemisphere has a seasonal variability with an amplitude of 3.2 ppm from 2009 to 2011. Further comparisons between our station and other TCCON sta- 
(a)

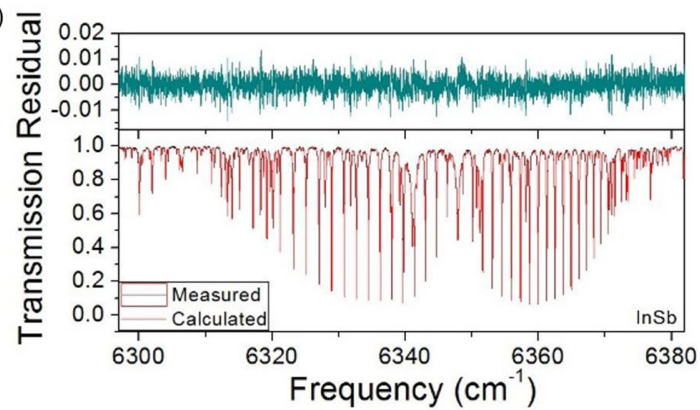

(b)

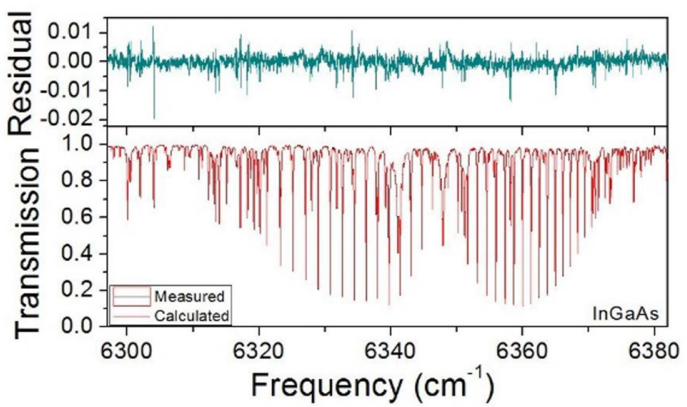

Figure 6. Spectral fitting of $\mathrm{CO}_{2}$ in spectral window of $6297-6382 \mathrm{~cm}^{-1}$ using an InSb detector (a) and InGaAs detector (b).

(a)

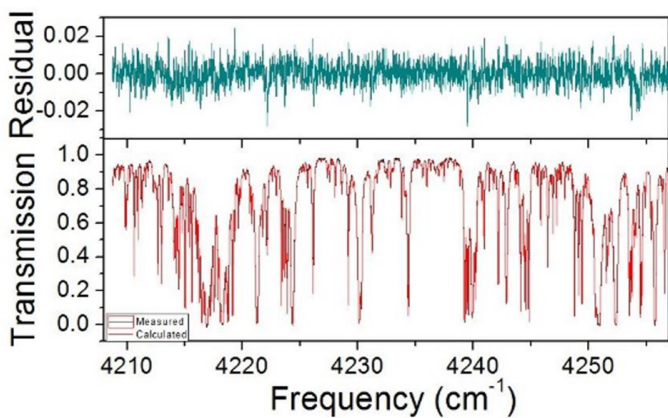

(b)

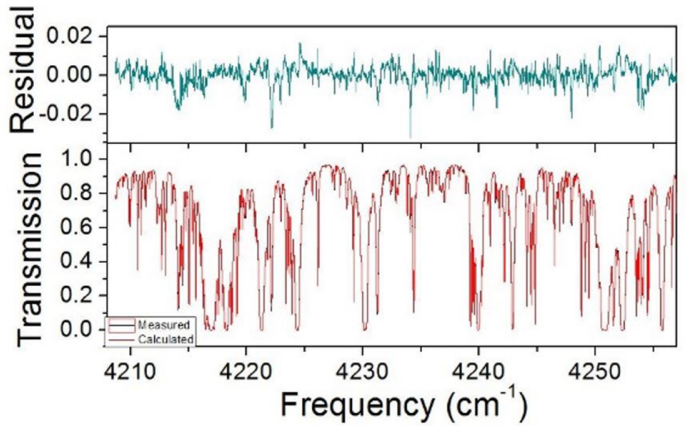

Figure 7. Spectral fitting of CO in spectral window of $4208-4257 \mathrm{~cm}^{-1}$ using an InSb detector (a) and InGaAs detector (b).

tions, GOSAT and OCO-2 data are described below. We conclude that the variation of $\mathrm{XCO}_{2}$ in the Hefei area is in accord with the variation in other midlatitude Northern Hemisphere locations, both in the trend and phase of the seasonal cycle.

In the case of XCO, the individual values and daily averages showed no obvious seasonal variations (Fig. 12). Dayto-day variations were considerable in the daily average of $\mathrm{XCO}$, ranging from $78.35 \pm 2.03$ to $171.60 \pm 3.00 \mathrm{ppb}$. The seasonal cycle of monthly average XCO is not clearly discernible, because it is concealed by the large daily variability due to local influences. There is variability on a seasonal timescale, showing a late autumn minimum and spring maximum from September 2015 to March 2016. The main source for $\mathrm{CO}$ in this area is incomplete combustion of fossil fuels, so the seasonal behaviour of XCO may reveal the variability of $\mathrm{CO}$ emission from vehicle exhaust.

In recent publications of Liu et al. (2011), satellite measurements and model simulations showed that monthly mean of $\mathrm{CO}$ vertical column density had a maximum in winter and minimum in summer in the eastern area of China (20 to $40^{\circ} \mathrm{N}, 107$ to $123^{\circ} \mathrm{E}$ ) in 2004 and 2005 . Angelbratt et al. (2011) estimated the trends of the CO partial columns from four European ground-based FTS stations, obtaining obvious seasonal variation during the year from 1996 to 2006. In de Laat et al. (2010), ground-based observations indicated that the time series of CO total column in the Northern Hemisphere midlatitude area had clear seasonal varia- tions, with a wintertime maximum and summertime minimum due to photochemical reaction with $\mathrm{OH}$ radical for the 2003-2007 time period. However, in our observations, time series of individual XCO and their daily and monthly mean values showed no seasonal variation. The pattern may be due to the complicated emission of CO sources in the Hefei area.

Diurnal variation can be obtained by analysing data on a daily timescale. 24 October 2014 is selected because the data sampled on this clear-sky day cover long daylight hours and are continuous. Figure 13 documents that the total column of both species were higher at noon (UT +8$)$, displaying similar behaviour on this day. $\mathrm{XCO}_{2}$ and $\mathrm{XCO}$ climbed to maximum at noon, then dropped slowly until sunset. The prevailing wind direction on this day was from the south-east, resulting in urban regional emission superimposed on background emissions. The midday peaks for each gas reflect the influence of anthropogenic emissions.

We calculate the daily anomalies by subtracting the morning DMF value at a particular solar zenith angle (SZA) from its afternoon counterpart using the method of Wunch et al. (2009). This method eliminates the spurious correlations caused by SZA- or air mass-dependent errors. Figure 14 presents the relationship between the anomalies of XCO and $\mathrm{XCO}_{2}$ on daily scale, the linear regression line shows the good correlation (correlation coefficient $R^{2}=0.58$ ) between them on 24 October. Atmospheric $\mathrm{CO}$ and $\mathrm{CO}_{2}$ are generated from common combustion sources. The strong correla- 
(a)

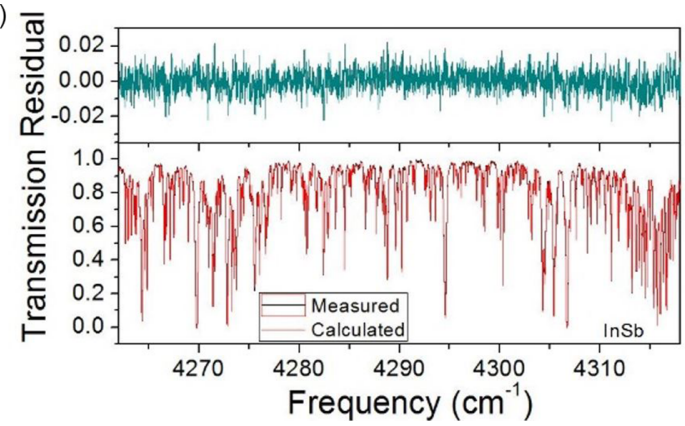

(b)

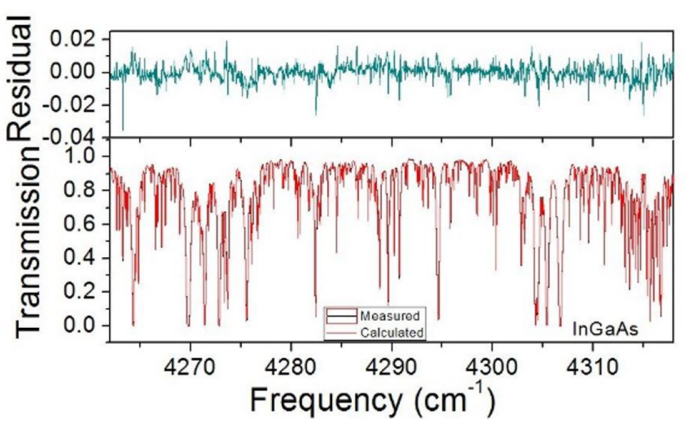

Figure 8. Spectral fitting of CO in spectral window of $4242-4318 \mathrm{~cm}^{-1}$ using an InSb detector (a) and InGaAs detector (b).

(a)

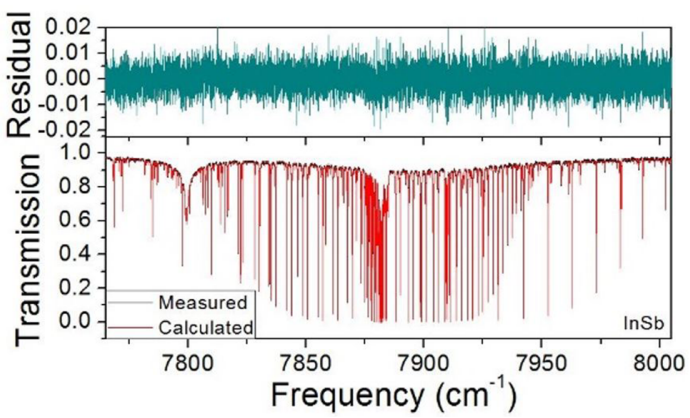

(b)

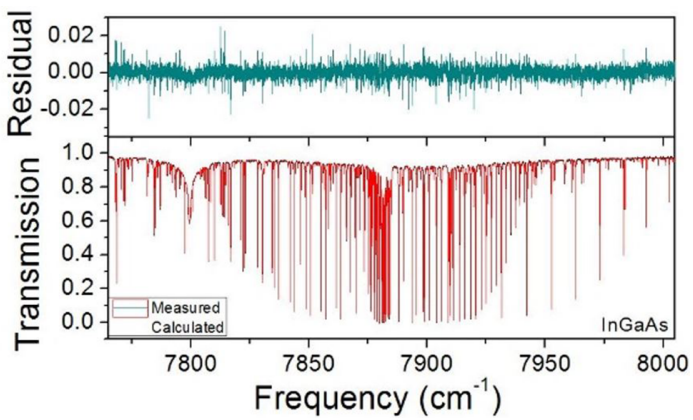

Figure 9. Spectral fitting of $\mathrm{O}_{2}$ in spectral window of $7765-8005 \mathrm{~cm}^{-1}$ using an InSb detector (a) and InGaAs detector (b).

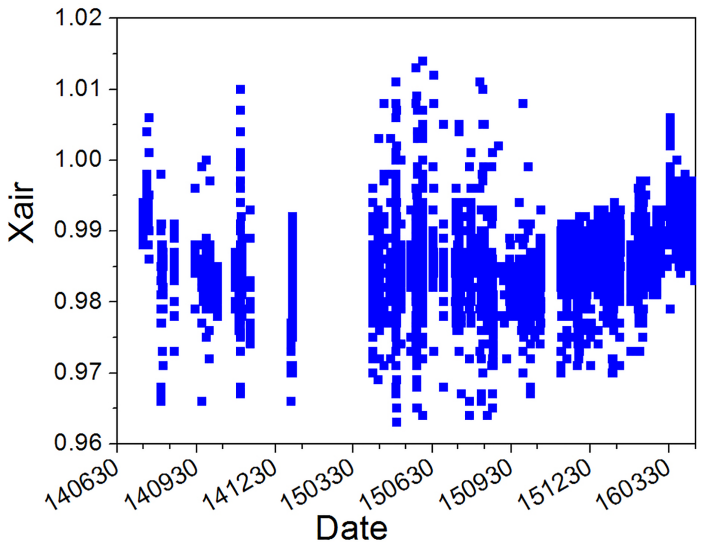

Figure 10. Time series of retrieved Xair.

tion between $\mathrm{CO}$ and $\mathrm{CO}_{2}$ indicates that there are strong influences of combustion emissions on $\mathrm{XCO}_{2}$. The correlation slope gives the emission ratio of $\mathrm{CO}$ to $\mathrm{CO}_{2}$, which varies with the sources of $\mathrm{CO}_{2}$, depending on different combustion types and biospheric activity. So the correlation slope of the anomalies of $\mathrm{XCO}$ to $\mathrm{XCO}_{2}$ provides a characteristic signature of source regions and source type (Suntharalingam et al., 2004; Wang et al., 2010). In our case, the correlation slope of $\mathrm{CO}$ to $\mathrm{CO}_{2}$ was $5.66 \mathrm{ppbpm}^{-1}(0.56 \%)$ on 24 October 2014.

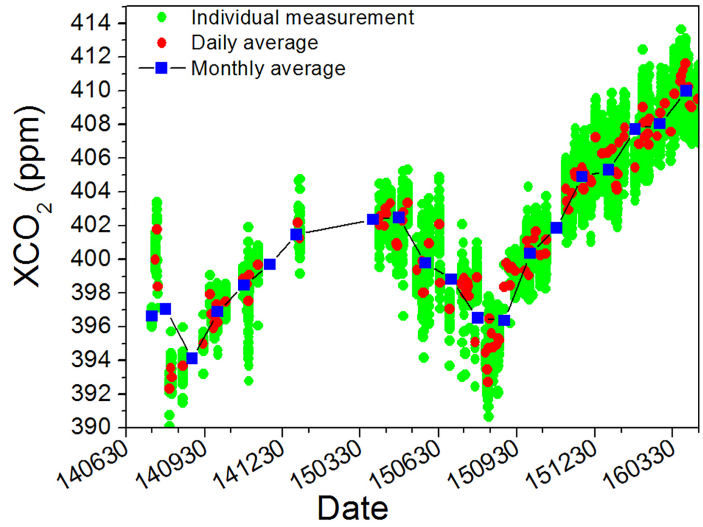

Figure 11. Time series of $\mathrm{XCO}_{2}$ from July 2014 to April 2016 at Hefei. The green circles indicate individual $\mathrm{XCO}_{2}$, the red circles represent daily averages of $\mathrm{XCO}_{2}$, the black lines with blue squares represent monthly averages of $\mathrm{XCO}_{2}$.

However, both gases varied considerably between days, and weak correlation in the variation of $\mathrm{CO}_{2}$ and $\mathrm{CO}$ appeared in some days. So the entire data during the observations displayed weak correlation (not shown). The prevailing wind was from south-east in winter and spring, while the wind was predominantly from south-west or north-west in summer and autumn during the measurement period. For our site, the urban area is in the south-east, and the instrument site is surrounded by croplands and wetlands. We analysed 


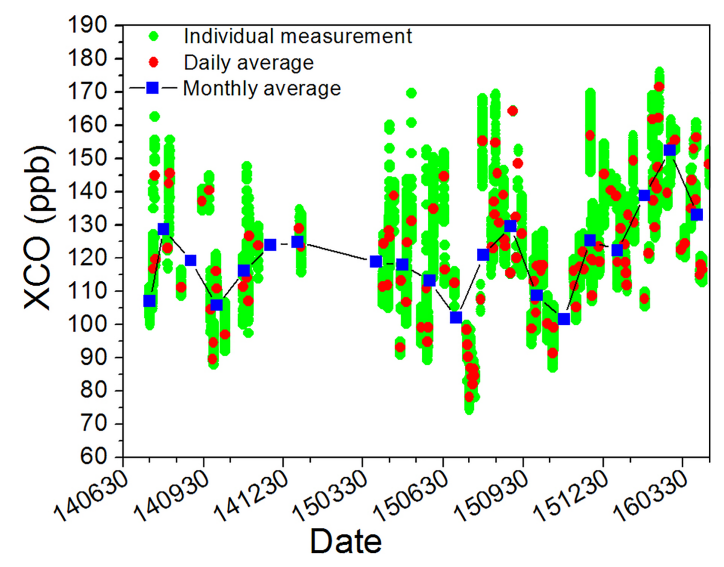

Figure 12. Time series of XCO from July 2014 to April 2016 at Hefei. The green circles indicate individual XCO, the red circles represent daily averages of $\mathrm{XCO}$, the black lines with blue squares represent monthly averages of XCO.

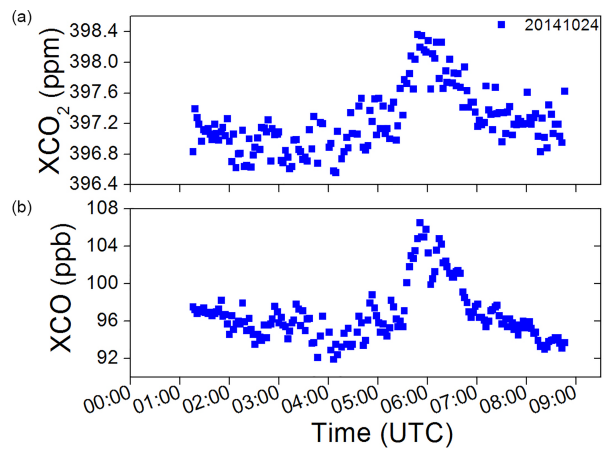

Figure 13. Time series of $\mathrm{XCO}_{2}$ (a) and $\mathrm{XCO}(\mathbf{b})$ on 24 October 2014.

the relationship of the daily average of anomalies of XCO and $\mathrm{XCO}_{2}$ under different prevailing wind conditions and found that the correlations in winter and spring as well as in summer and autumn are also weak. So correlations are only observable for individual days, e.g. 24 October 2014. In the study of Wunch et al. (2009), the slope of the anomaly correlations of $\mathrm{XCO}$ to $\mathrm{XCO}_{2}$ was $11 \pm 2 \mathrm{ppbpm}^{-1}$ in a densely populated urban region (the South Coast Air Basin around Los Angeles). Wang et al. (2010) calculated the overall $\mathrm{CO}_{2} / \mathrm{CO}$ correlation slope at a rural site near Beijing in China during 2007-2008 excluding the summer data, and the corresponding $\mathrm{CO} / \mathrm{CO}_{2}$ ratio was $41.7 \mathrm{ppb} \mathrm{ppm}^{-1}$. The correlation slopes calculated on daily scale at our site are usually smaller than the reported values in Beijing (Wang et al., 2010 and references therein), which are primarily attributed to the smaller emission in $\mathrm{CO}$.

\subsection{Comparison with the observations of EM27/SUN}

A portable low-resolution $\left(0.5 \mathrm{~cm}^{-1}\right)$ FTS (EM27/SUN) has been used for observation of $\mathrm{XCO}_{2}$ and $\mathrm{XCH}_{4}$ since Oc-

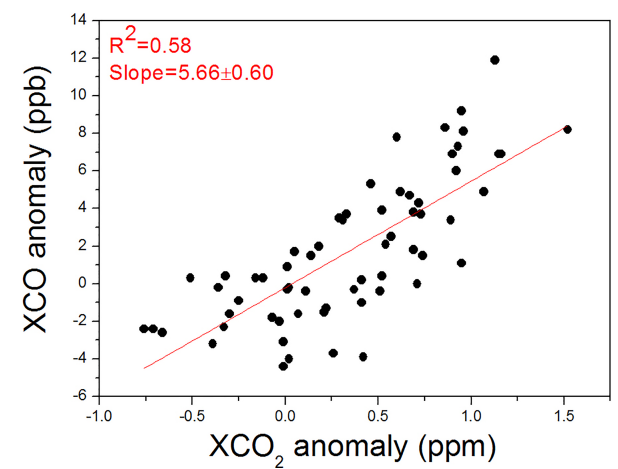

Figure 14. Correlation between the anomalies of $\mathrm{XCO}_{2}$ and $\mathrm{XCO}$ on 24 October 2014.

tober 2016. GFIT is also used for trace gas retrieval from the EM27 spectra, with the same parameters as used for high-resolution FTS spectra. The observation results from the high-resolution 125HR are compared with the temporally coinciding measurements taken with EM27/SUN in Fig. 15, which presents the comparison of the $\mathrm{XCO}_{2}$ values for 4 sample days. The intraday variability is clearly observed by the two spectrometers. There are systematic differences between the two measurements due to different spectral resolutions, different averaging kernels and spectroscopic inadequacies (Gisi et al., 2012; Hedelius et al., 2017). The differences are about $1.35 \mathrm{ppm}(0.33 \%)-1.55 \mathrm{ppm}(0.38 \%)$ for $\mathrm{XCO}_{2}$. Also, we calculated the daily averages of $\mathrm{XCO}_{2}$ to compare the results during the period from November 2016 to February 2017. Ratioing the daily averaged $\mathrm{XCO}_{2}$ of EM27and FTS gives an overall calibration factor of $0.996 \pm 0.001$ (mean \pm standard deviation of the ratios of EM27 to FTS $\mathrm{XCO}_{2}$ ), as illustrated in Fig. 16. We will use the EM27/SUN as a travel standard to compare our measurements to TCCON in the future (and if necessary calibrate our measurements), especially when taking aircraft and AirCore profile measurements is difficult.

\subsection{Comparison with nearby TCCON observations}

We compare our data with similar ground-based highresolution observations at Tsukuba TCCON station $\left(36^{\circ} 5^{\prime} \mathrm{N}\right.$, $140^{\circ} 7^{\prime} \mathrm{E}$ ) in Japan, because Tsukuba station is the nearest TCCON station to our site and at a similar latitude (Morino et al., 2014). In order to show the comparison clearly, we also depict the daily averaged $\mathrm{XCO}_{2}$ of two sites from July 2014 to April 2016 in Fig. 17. As can be seen, variations of $\mathrm{XCO}_{2}$ at the Tsukuba site agreed well with those at the Hefei site. The daily averaged $\mathrm{XCO}_{2}$ exhibited the same seasonal cycle as that of our site. The lowest $\mathrm{XCO}_{2}$ appeared in late summer (August and September), and the highest value was in spring (April). The seasonal amplitudes are 8.74 and $9.27 \mathrm{ppm}$ in the years 2014-2015 and 2015-2016 from monthly average 

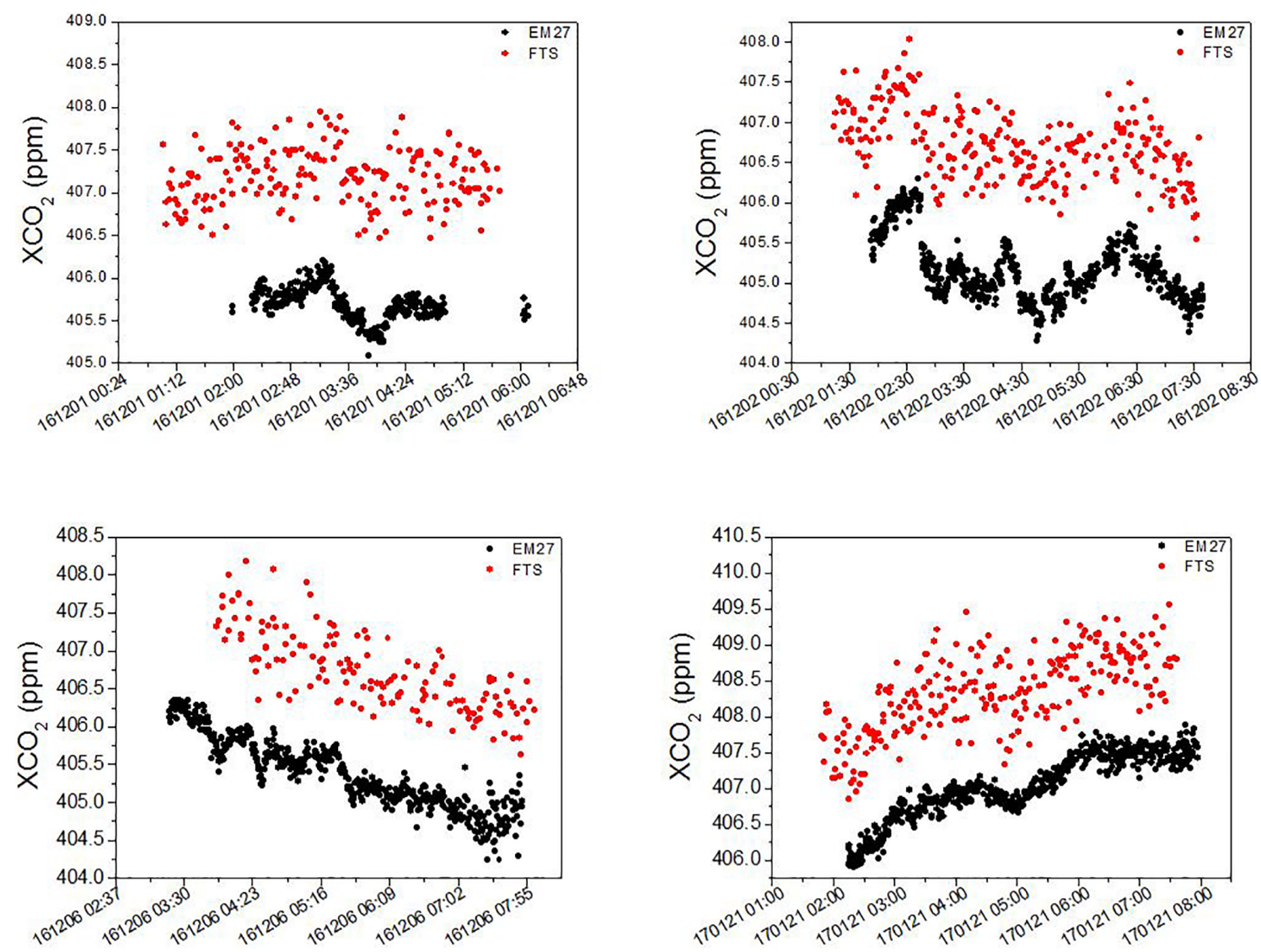

Figure 15. Retrieved $\mathrm{XCO}_{2}$ values based on EM27 and IFS125HR on 4 sample days.

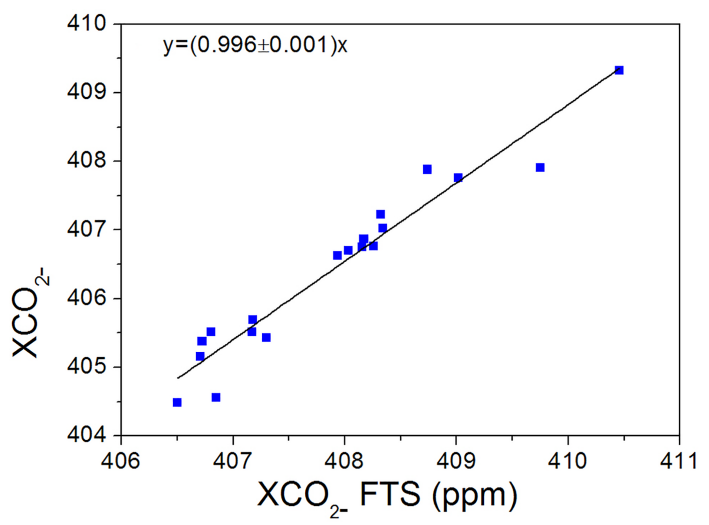

Figure 16. Daily averages of $\mathrm{XCO}_{2}$ measured by the EM27/SUN plotted against the corresponding values of the FTS. The line shows the best fit to the ratio of EM27 to FTS $\mathrm{XCO}_{2}$.

respectively, which is comparable to the corresponding values at our site.

Similarly, daily averages of XCO at Tsukuba station are plotted with those at our Hefei site in Fig. 18. Trends of $\mathrm{XCO}$ at Tsukuba were broadly consistent with those at the Hefei site, but XCO varied substantially between days, and

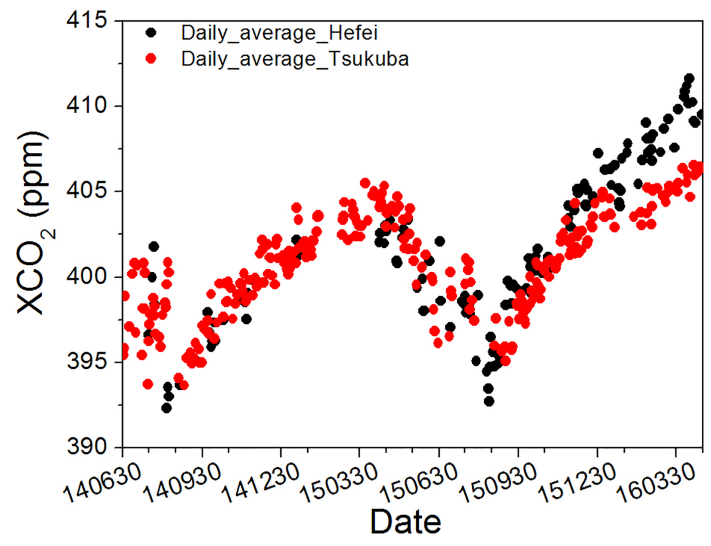

Figure 17. Comparison of daily averaged $\mathrm{XCO}_{2}$ at the Hefei and Tsukuba sites. The black and red circles indicate values at Hefei and Tsukuba respectively.

the daily average showed no obvious seasonal variation. The daily average of XCO at Tsukuba station spanned from 71.69 to $144.57 \mathrm{ppb}$, falling in the range of our daily average value. The largest XCO was in spring (April) and the lowest value in autumn (October), and the seasonal amplitude is $27.21 \mathrm{ppb}$ at Tsukuba. The $\mathrm{CO}$ variability is driven by local effects (for ex- 


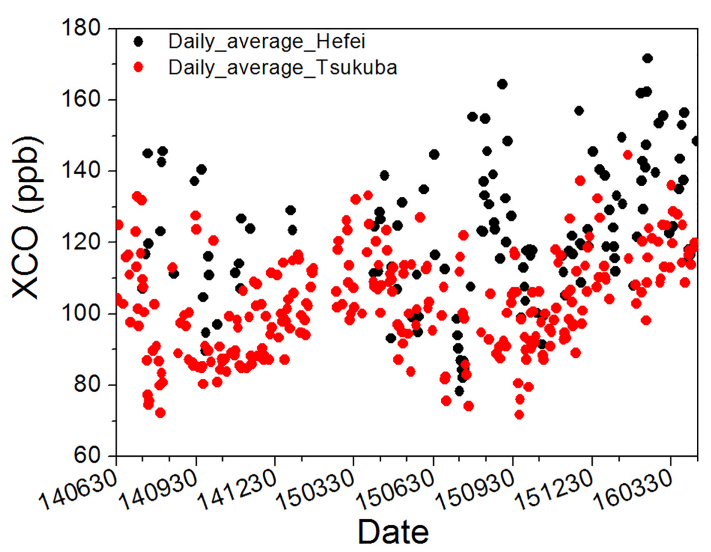

Figure 18. Comparison of daily averaged XCO at the Hefei and Tsukuba sites. The black and red circles indicate values at Hefei and Tsukuba respectively.

Table 4. Satellite data filtering criteria for GOSAT and OCO-2.

\begin{tabular}{lr}
\hline Variable (OCO-2 version 7 Br ) & Criteria \\
\hline XCO$_{2}$ quality_flag & 0 \\
warn_level & $\leq 14$ \\
Variable (NIES-GOSAT) & Criteria \\
Data/retrievalQuality/totalPostScreeningResult & 0 \\
scanAttribute/qualityInformation/totalPreScreeningResult & 0 \\
\hline
\end{tabular}

ample combustion) rather than global-scale effects for $\mathrm{CO}_{2}$, so the variation of $\mathrm{CO}$ in Tsukuba appears to be different from that in Hefei.

\subsection{Comparison with satellite data}

To further evaluate our retrieved data, we compared satellite measurements with the results. GOSAT, OCO-2 and TANSAT are currently the dedicated satellites that map global atmospheric column amounts of $\mathrm{CO}_{2}$. Common targets of the satellite missions are observations of $\mathrm{XCO}_{2}$. For the comparison with ground-based FTS measurements, GOSAT Level 2 and OCO-2 Lite File product data within $4^{\circ}$ latitude/longitude radius of Hefei station were adopted. We set the collocation time to 1 day. The data-filtering criteria are summarized in Table 4.

In order to directly compare two measurements made by different remote-sensing instruments, their different a priori profiles and averaging kernels must be taken into account (Rodgers and Connor, 2003). Nguyen et al. (2014) found that TCCON data were corrected by the column averaging kernel of GOSAT retrievals, showing that the standard deviation of the difference between non-corrected and corrected TCCON data is $0.24 \mathrm{ppm}$. Wunch et al. (2011b) showed smoothing the TCCON profiles with the ACOS-GOSAT averaging kernel at Lamont results in a bias of about $0.6 \mathrm{ppm}$. Zhou et al. (2016) applied the a priori profile of TCCON data to correct the satellite retrievals and found that the difference be- tween a priori-corrected and original satellite $\mathrm{XCO}_{2}$ ranged from -0.6 to $0.3 \mathrm{ppm}$. Ohyama et al. (2015) used a common a priori profile and column averaging kernel corrections, found that the effects of differences in a priori profile and column averaging kernel are small. The average differences between the adjusted and the original GOSAT $\mathrm{XCO}_{2}$ data is $-0.02 \pm 0.17 \mathrm{ppm}$, and the average difference between the smoothed and original TCCON $\mathrm{XCO}_{2}$ data is -0.08 $\pm 0.12 \mathrm{ppm}$. The results indicate that the impact of applying or not applying the a priori profiles and averaging kernels for $\mathrm{XCO}_{2}$ comparisons is small compared to difference between satellite and FTS data. However, it is not trivial to consider averaging kernels for a comparison of different remote sensing observations, and this requires actual variability of $\mathrm{CO}_{2}$ profiles, which is unknown for our site at present. Therefore, we compared the satellite and FTS data directly, without considering the effect of different a priori profiles and averaging kernels.

Comparisons of daily median $\mathrm{XCO}_{2}$ were carried out, because the temporal coverage is substantially different between our ground-based measurements and space-based observations. Figure 19 provides the direct comparison of our data with respect to the co-located GOSAT data. Although there are not a lot of data according to this coincidence criteria, it is found that our daily median $\mathrm{XCO}_{2}$ data are in broad agreement with the GOSAT data. The mean difference between satellite $\mathrm{XCO}_{2}$ and ground-based FTS $\mathrm{XCO}_{2}$ is computed as a bias (satellite data minus FTS data), and the standard deviation of the difference is also calculated. There are 40 pairs of data for daily median $\mathrm{XCO}_{2}$, giving a negative bias of $-0.52 \mathrm{ppm}$ and standard deviation of $1.63 \mathrm{ppm}$. The correlation coefficients $\left(R^{2}\right)$ are 0.79 for daily median values. The scatter graphs of the retrieval results of GOSAT and FTS in Fig. 19 show a good linear relationship.

Morino et al. (2011) validated GOSAT $\mathrm{XCO}_{2}$ and $\mathrm{XCH}_{4}$ data with ground-based FTS data from nine TCCON stations and showed that the mean difference between the satellite $\mathrm{XCO}_{2}$ data and FTS data was $-8.85 \pm 4.75 \mathrm{ppm}$, with a correlation coefficient of 0.378 . Using a newer GOSAT retrieval algorithm, Yoshida et al. (2013) improved the $\mathrm{XCO}_{2}$ retrieval from GOSAT, achieving negative biases of $-1.48 \mathrm{ppm}$ and standard deviations of $2.09 \mathrm{ppm}$ compared to TCCON data. Guerlet et al. (2013) compared GOSAT $\mathrm{XCO}_{2}$ data using cloud and aerosol filters in the retrieval with colocated TCCON measurements, displaying a mean bias of $-1.4 \pm 2.5 \mathrm{ppm}$. Dils et al. (2014) showed that the satellite $\mathrm{XCO}_{2}$ data retrieved by two different algorithms relative to FTS data produced a mean bias of $-0.76 \pm 2.37$ and $-0.57 \pm 2.50 \mathrm{ppm}$ respectively. Nguyen et al. (2014) found that $\mathrm{XCO}_{2}$ data from GOSAT retrievals compared to groundbased TCCON $\mathrm{XCO}_{2}$ measurements using three co-location methodologies displayed a positive bias in the range of 0.39 to $4.07 \mathrm{ppm}$, with standard deviations of 0.39 to $2.37 \mathrm{ppm}$, and correlation coefficient from 0 to 0.90 . In recent studies of Heymann et al. (2015), Ohyama et al. (2015) and Kulawik et 

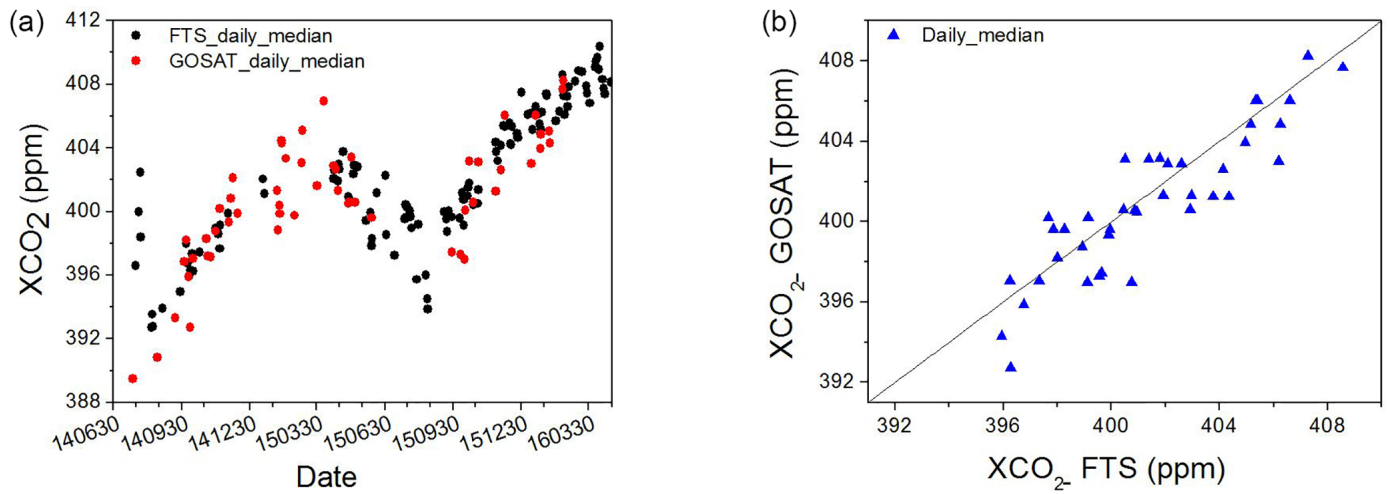

Figure 19. Comparison of ground-based observations with retrieved data from GOSAT, including daily median $\mathrm{XCO}_{2}$ (a) and scatter graphs of daily median $\mathrm{XCO}_{2}$ (b).
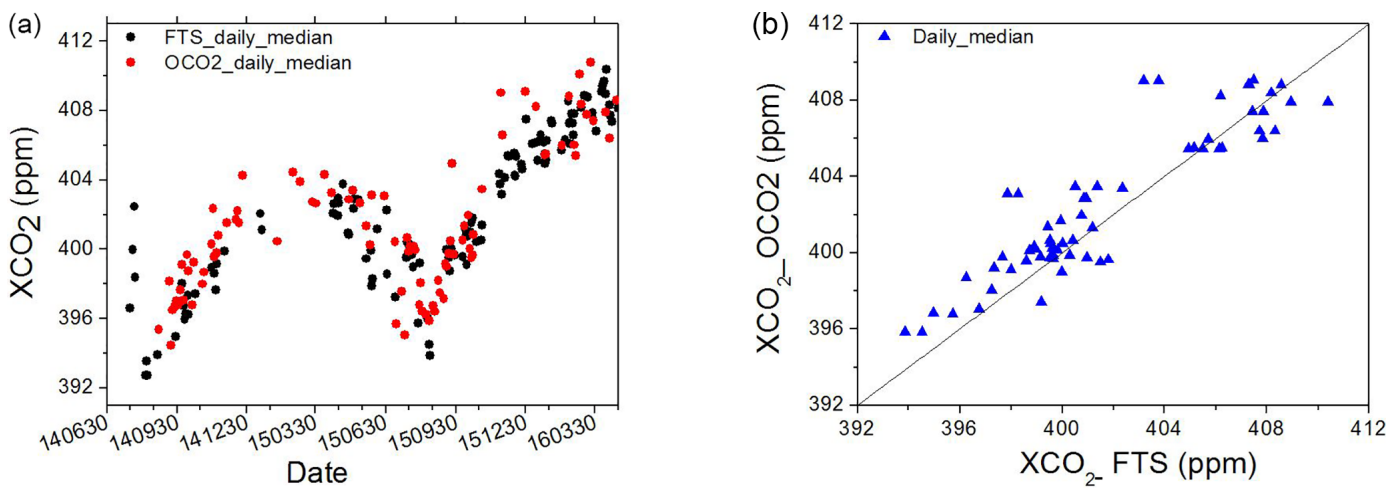

Figure 20. Comparison of ground-based observations with retrieved data from OCO2, including daily median $\mathrm{XCO}_{2}(\mathbf{a})$ and scatter graphs of daily mean $\mathrm{XCO}_{2}(\mathbf{b})$.

al. (2016), the comparison results also demonstrate the consistency between GOSAT $\mathrm{XCO}_{2}$ and TCCON $\mathrm{XCO}_{2}$. They found that the average differences between TANSO-FTS and ground-based FTS data were $-0.34 \pm 1.37,0.40 \pm 2.51$ and $0.48 \pm 1.68 \mathrm{ppm}$, with correlation coefficients of $0.86,0.87$ and 0.74 . So the average differences between TANSO-FTS and our FTS data and standard deviations of the differences are within the range of comparison results from other TCCON site data, and the correlation coefficients are comparable to that of other comparison results.

We used OCO-2 version 7Br data (bias-corrected Lite File product) for comparison with our site. Figure 20 presents the comparison of our data with respect to OCO-2 data. There are 62 daily median OCO- 2 data that can be compared to the corresponding ground-based FTS data, yielding a positive bias of $0.81 \mathrm{ppm}$ and standard deviation of $1.73 \mathrm{ppm}$ respectively. The correlation coefficient $\left(R^{2}\right)$ is 0.83 for the daily median $\mathrm{XCO}_{2}$. The differences between FTS and OCO2 data are slightly larger than those of FTS and GOSAT. The right panel of Fig. 20 shows the scatter graphs for retrieval results of OCO-2 and FTS, displaying a fairly good linear relationship.
Recent studies of Wunch et al. (2017) compared the OCO2 version $7 \mathrm{Br}$ data with ground-based TCCON data, showing that the median differences between OCO- 2 and TCCON data were less than $0.5 \mathrm{ppm}$, with the rms differences below $1.5 \mathrm{ppm}$ and correlation coefficients from 0.50 to 0.75 for ocean glint mode, land glint mode and nadir mode. For our comparison, the correlations are slightly better than that of other comparison results, while the differences of biascorrected OCO-2 data from our FTS data and standard deviations are larger than those of other TCCON site data. The comparison results demonstrated that our ground-based FTS measurements are broadly consistent with the OCO-2 observations.

\section{Conclusions}

A solar observatory deployed at Hefei China has collected near-infrared solar spectra since July 2014. Total columns of atmospheric $\mathrm{CO}_{2}$ and $\mathrm{CO}$ have been successfully retrieved from high-resolution ground-based FTS measurements. The spectra collected using an InSb detector in the first year were compared with those collected by an InGaAs detector from 
July 2015, showing that InGaAs spectra have approximately two times better signal-to-noise ratios, and correspondingly smaller rms spectral fitting residuals compared to InSb spectra. Consequently, the measurement precision of retrieved $\mathrm{XCO}_{2}$ and $\mathrm{XCO}$ for InGaAs spectra is superior to $\mathrm{InSb}$ spectra, with about 0.04 and $0.09 \%$ for $\mathrm{XCO}_{2}$, and 1.07 and $2.00 \%$ for XCO within clear-sky days respectively. Daily and monthly averaged values for $\mathrm{XCO}_{2}$ showed an obvious seasonal cycle, while daily and monthly averages of XCO displayed no clear seasonal variation. We analysed the relationship of the anomalies of $\mathrm{XCO}$ and $\mathrm{XCO}_{2}$, found that the correlations are only observable for individual days, and the data under different prevailing wind conditions during the observations displayed weak correlation. The correlation slopes calculated in individual days are usually smaller than the reported values in Beijing, China.

Our observations were compared with the temporally coinciding measurements taken with a portable low-resolution FTS (EM27/SUN). The systematic differences between the two measurements are about $1.35 \mathrm{ppm}(0.33 \%)-1.55 \mathrm{ppm}$ $(0.38 \%)$ for $\mathrm{XCO}_{2}$. Ratioing the daily averaged $\mathrm{XCO}_{2}$ of EM27 and FTS gives an overall calibration factor of $0.996 \pm 0.001$ (mean \pm standard deviation of the ratios of EM27 to FTS $\mathrm{XCO}_{2}$ ). Also, ground-based observations at Tsukuba TCCON station in Japan were compared with our observations. The results showed that the variation phase and seasonal amplitude of $\mathrm{XCO}_{2}$ are similar to our results, but the variation of XCO in Tsukuba looks different from our data in Hefei. To further evaluate the quality of our retrieved data, we made use of satellite measurements by comparing them with the results. The direct comparison of GOSAT data with our FTS results suggests that daily median $\mathrm{XCO}_{2}$ are in good agreement, giving biases of $-0.52 \mathrm{ppm}$ and standard deviation of $1.63 \mathrm{ppm}$ respectively. The correlation coefficient $\left(R^{2}\right)$ is 0.79 for the daily median $\mathrm{XCO}_{2}$ between our FTS measurement and GOSAT observations respectively. Daily median OCO-2 data produce a positive bias of $0.81 \mathrm{ppm}$ and standard deviation of $1.73 \mathrm{ppm}$ relative to ground-based data. Our daily median $\mathrm{XCO}_{2}$ show a strong correlation with OCO-2 observations, with correlation coefficient $\left(R^{2}\right)$ of 0.83 . The results show that our observations using ground-based FTS are very consistent with the GOSAT and OCO-2 observations. The comparison results have demonstrated the ability of our ground-based FTS to detect daily variations and reveal seasonal changes of atmospheric $\mathrm{CO}_{2}$ and $\mathrm{CO}$, as well as the ability to validate the satellite observations. It is important that the Hefei site can discern the Northern Hemisphere seasonal cycle of $\mathrm{CO}_{2}$ with the late summer minimum.

The observations described here present a means of precise remote sensing of atmospheric constituents in the Hefei area. Column values obtained from this site will help to determine the $\mathrm{CO}_{2}$ and $\mathrm{CO}$ sources and sinks in eastern China, where measurements are currently scarce. However, the results derived here need to be compared to in situ measure- ments based on the World Meteorological Organization's (WMO) gas scale. We have not yet compared our data to vertical profile measurements of instruments aboard aircraft or a balloon-borne AirCore system. The improvements will enhance the level of accuracy in the near future. Therefore, further research should utilize in situ measurements or model simulations to verify the observations.

Data availability. The GFIT algorithm is obtained from TCCON website (https://tccon-wiki.caltech.edu). The LINEFIT14.5 software is obtained on request from KIT Karlsruhe (http://www.imk-asf.kit.edu/english/897.php). The OCO2 satellite data are downloaded from the website (http://disc.sci.gsfc.nasa.gov/uui/datasets/OCO2_L2_Lite_FP_ V7r/summary?keywords=OCOACOS). The GOSAT satellite data are downloaded from the website (GDAS site: https://data2.gosat.nies.go.jp/). The used data are attached as a Supplement (data set).

\section{The Supplement related to this article is available online at https://doi.org/10.5194/amt-10-2627-2017-supplement.}

Competing interests. The authors declare that they have no conflict of interest.

Acknowledgements. We gratefully acknowledge the support of the National Natural Science Foundation of China (41405134; 41575021; 91544212; 41605018), the National Key Technology R\&D Program of China (2016YFC0200800), and Anhui Province Natural Science Foundation of China (Grant No. 1308085MD79) for conducting this research. VAV and DWTG would like to acknowledge financial support from the Australian Research Council (DP160101598, DP140101552, DP110103118). We thank the members of the GOSAT Project for providing us with the GOSAT L2 data products. We also thank the members of the OCO Project for providing the OCO-2 Lite file product data. We greatly appreciate the technical help from Karlsruhe Institute of Technology (KIT), Institute for Meteorology and Climate Research (IMK-ASF), Karlsruhe, Germany for calibration of EM27/SUN and California Institute of Technology, Pasadena, CA, USA for retrieval code of EM27/SUN.

Edited by: Andre Butz

Reviewed by: two anonymous referees

\section{References}

Angelbratt, J., Mellqvist, J., Simpson, D., Jonson, J. E., Blumenstock, T., Borsdorff, T., Duchatelet, P., Forster, F., Hase, F., Mahieu, E., De Mazière, M., Notholt, J., Petersen, A. K., Raffalski, U., Servais, C., Sussmann, R., Warneke, T., and Vigouroux, 
C.: Carbon monoxide $(\mathrm{CO})$ and ethane $\left(\mathrm{C}_{2} \mathrm{H}_{6}\right)$ trends from ground-based solar FTIR measurements at six European stations, comparison and sensitivity analysis with the EMEP model, Atmos. Chem. Phys., 11, 9253-9269, https://doi.org/10.5194/acp11-9253-2011, 2011.

Boesch, H., Baker, D., Connor, B., Crisp, D., and Miller, C.: Global Characterization of $\mathrm{CO}_{2}$ Column Retrievals from Shortwave-Infrared Satellite Observations of the Orbiting Carbon Observatory-2 Mission, Remote Sensing, 3, 270-304, https://doi.org/10.3390/rs3020270, 2011.

Bovensmann, H., Burrows, J. P., Buchwitz, M., Frerick, J., Noel, S., Rozanov, V. V., Chance, K. V., and Goede, A.: SCIAMACHYMission Objectives and Measurement Modes, J. Atmos. Sci., 56, 127-150, 1999.

Bovensmann, H., Buchwitz, M., Frerick, J., Hoogeveen, R.,Kleipool, Q., Lichtenberg, G., Noel, S., Richter, A., Rozanov,A., Rozanov, V. V., Skupin, J., von Savigny, C., Wuttke, M., and Burrows, J. P.: SCIAMACHY on ENVISAT: In-fight optical performance and first results, in: Remote Sensing of Clouds and the Atmosphere VIII, edited by: Schafer, K. P., Comeron, A., Carleer, M. R., and Picard, R. H., Proc. SPIE, 5235, 160-173, 2004.

Buchholz, R. R., Paton-Walsh, C., Griffith, D. W. T., Kubistin, D., Caldow, C., Fisher, J. A., Deutscher, N. M., Kettlewell, G., Riggenbach, M., Macatangay, R., Krummel, P. B., and Langenfelds, R. L.: Source and meteorological influences on air quality $\left(\mathrm{CO}, \mathrm{CH}_{4} \& \mathrm{CO}_{2}\right)$ at a Southern Hemisphere urban site, Atmos. Environ. 126, 274-289, https://doi.org/10.1016/j.atmosenv.2015.11.041, 2016.

Butz, A., Guerlet, S., Hasekamp, O., Schepers, D., Galli, A., Aben, I., Frankenberg, C., Hartmann, J.-M., Tran, H., Kuze, A., Keppel-Aleks, G., Toon, G., Wunch, D., Wennberg, P., Deutscher, N., Griffith, D., Macatangay, R., Messerschmidt, J., Notholt, J., and Warneke, T.: Toward accurate $\mathrm{CO}_{2}$ and $\mathrm{CH}_{4}$ observations from GOSAT, Geophys. Res. Lett., 38, L14812, https://doi.org/10.1029/2011GL047888, 2011.

Clerbaux, C., George, M., Turquety, S., Walker, K. A., Barret, B., Bernath, P., Boone, C., Borsdorff, T., Cammas, J. P., Catoire, V., Coffey, M., Coheur, P.-F., Deeter, M., De Mazière, M., Drummond, J., Duchatelet, P., Dupuy, E., de Zafra, R., Eddounia, F., Edwards, D. P., Emmons, L., Funke, B., Gille, J., Griffith, D. W. T., Hannigan, J., Hase, F., Höpfner, M., Jones, N., Kagawa, A., Kasai, Y., Kramer, I., Le Flochmoën, E., Livesey, N. J., López-Puertas, M., Luo, M., Mahieu, E., Murtagh, D., Nédélec, P., Pazmino, A., Pumphrey, H., Ricaud, P., Rinsland, C. P., Robert, C., Schneider, M., Senten, C., Stiller, G., Strandberg, A., Strong, K., Sussmann, R., Thouret, V., Urban, J., and Wiacek, A.: CO measurements from the ACE-FTS satellite instrument: data analysis and validation using ground-based, airborne and spaceborne observations, Atmos. Chem. Phys., 8, 2569-2594, https://doi.org/10.5194/acp-8-2569-2008, 2008.

Crisp, D., Atlas, R. M., Breon, F.-M., Brown, L. R., Burrows, J. P., Ciais, P., Connor, B. J., Doney, S. C., Fung, I. Y., Jacob, D. J., Miller, C. E., O’Brien, D., Pawson, S., Randerson, J. T., Rayner, P., Salawitch, R. J., Sander, S. P., Sen, B., Stephens, G. L., Tans, P. P., Toon, G. C., Wennberg, P. O., Wofsy, S. C., Yung, Y. L., Kuang, Z., Chudasama, B., Sprague, G., Weiss, B., Pollock, R., Kenyon, D., and Schroll, S.: The Orbiting Carbon Observatory (OCO) mission, Adv. Space Res., 34, 700-709, 2004. de Laat, A. T. J., Gloudemans, A. M. S., Schrijver, H., Aben, I., Nagahama, Y., Suzuki, K., Mahieu, E., Jones, N. B., Paton-Walsh, C., Deutscher, N. M., Griffith, D. W. T., De Mazière, M., Mittermeier, R. L., Fast, H., Notholt, J., Palm, M., Hawat, T., Blumenstock, T., Hase, F., Schneider, M., Rinsland, C., Dzhola, A. V., Grechko, E. I., Poberovskii, A. M., Makarova, M. V., Mellqvist, J., Strandberg, A., Sussmann, R., Borsdorff, T., and Rettinger, M.: Validation of five years (2003-2007) of SCIAMACHY CO total column measurements using ground-based spectrometer observations, Atmos. Meas. Tech., 3, 1457-1471, https://doi.org/10.5194/amt-3-1457-2010, 2010.

Deutscher, N. M., Griffith, D. W. T., Bryant, G. W., Wennberg, P. O., Toon, G. C., Washenfelder, R. A., Keppel-Aleks, G., Wunch, D., Yavin, Y., Allen, N. T., Blavier, J.-F., Jiménez, R., Daube, B. C., Bright, A. V., Matross, D. M., Wofsy, S. C., and Park, S.: Total column $\mathrm{CO}_{2}$ measurements at Darwin, Australia - site description and calibration against in situ aircraft profiles, Atmos. Meas. Tech., 3, 947-958, https://doi.org/10.5194/amt-3947-2010, 2010.

Dils, B., Buchwitz, M., Reuter, M., Schneising, O., Boesch, H., Parker, R., Guerlet, S., Aben, I., Blumenstock, T., Burrows, J. P., B utz, A., Deutscher, N. M., Frankenberg, C., Hase, F., Hasekamp, O. P., Heymann, J., De Mazière, M., Notholt, J., Sussmann, R., Warneke, T., Griffith, D., Sherlock, V., and Wunch, D.: The Greenhouse Gas Climate Change Initiative (GHG-CCI): comparative validation of GHG-CCI SCIAMACHY/ENVISAT and TANSO-FTS/GOSAT $\mathrm{CO}_{2}$ and $\mathrm{CH}_{4}$ retrieval algorithm products with measurements from the TCCON, Atmos. Meas. Tech., 7, 1723-1744, https://doi.org/10.5194/amt-7-1723-2014, 2014.

Dohe, S.: Measurements of atmospheric $\mathrm{CO}_{2}$ columns using ground-based FTIR spectra, Doctoral thesis, Karlsruher Institute of Technology, 2013.

Frankenberg, C., Pollock, R., Lee, R. A. M., Rosenberg, R., Blavier, J.-F., Crisp, D., O’Dell, C. W., Osterman, G. B., Roehl, C., Wennberg, P. O., and Wunch, D.: The Orbiting Carbon Observatory (OCO-2): spectrometer performance evaluation using prelaunch direct sun measurements, Atmos. Meas. Tech., 8, 301313, https://doi.org/10.5194/amt-8-301-2015, 2015.

Gisi, M., Hase, F., Dohe, S., Blumenstock, T., Simon, A., and Keens, A.: $\mathrm{XCO}_{2}$-measurements with a tabletop FTS using solar absorption spectroscopy, Atmos. Meas. Tech., 5, 2969-2980, https://doi.org/10.5194/amt-5-2969-2012, 2012.

Hamazaki, T., Kaneko, Y., Kuze, A., and Kondo, K.: Fourier transform spectrometer for greenhouse gases observing satellite (GOSAT), in: Enabling Sensor and Platform Technologies for Spaceborne Remote Sensing, edited by: Komar, G. J., Wang, J., and Kimura, T., Proc. SPIE, 5659, 73-80, https://doi.org/10.1117/12.581198, 2005.

Hase, F., Blumenstock, T., and Paton-Walsh, C.: Analysis of the instrumental line shape of high resolution Fourier transform IR spectrometers with gas cell measurements and new retrieval software, Appl. Opt., 38, 3417-3422, https://doi.org/10.1364/AO.38.003417,1999.

Hase, F.: Improved instrumental line shape monitoring for the ground-based, high-resolution FTIR spectrometers of the Network for the Detection of Atmospheric Composition Change, Atmos. Meas. Tech., 5, 603-610, https://doi.org/10.5194/amt-5603-2012, 2012. 
Hase, F., Drouin, B. J., Roehl, C. M., Toon, G. C., Wennberg, P. O., Wunch, D., Blumenstock, T., Desmet, F., Feist, D. G., Heikkinen, P., De Mazière, M., Rettinger, M., Robinson, J., Schneider, M., Sherlock, V., Sussmann, R., Té, Y., Warneke, T., and Weinzierl, C.: Calibration of sealed $\mathrm{HCl}$ cells used for TCCON instrumental line shape monitoring, Atmos. Meas. Tech., 6, 3527-3537, https://doi.org/10.5194/amt-6-3527-2013, 2013.

Hedelius, J. K., Parker, H., Wunch, D., Roehl, C. M., Viatte, C., Newman, S., Toon, G. C., Podolske, J. R., Hillyard, P. W., Iraci, L. T., Dubey, M. K., and Wennberg, P. O.: Intercomparability of $\mathrm{X}_{\mathrm{CO}_{2}}$ and $\mathrm{X}_{\mathrm{CH}_{4}}$ from the United States TCCON sites, Atmos. Meas. Tech., 10, 1481-1493, https://doi.org/10.5194/amt10-1481-2017, 2017.

Heymann, J., Reuter, M., Hilker, M., Buchwitz, M., Schneising, O., Bovensmann, H., Burrows, J. P., Kuze, A., Suto, H., Deutscher, N. M., Dubey, M. K., Griffith, D. W. T., Hase, F., Kawakami, S., Kivi, R., Morino, I., Petri, C., Roehl, C., Schneider, M., Sherlock, V., Sussmann, R., Velazco, V. A., Warneke, T., and Wunch, D.: Consistent satellite $\mathrm{XCO}_{2}$ retrievals from SCIAMACHY and GOSAT using the BESD algorithm, Atmos. Meas. Tech., 8, 2961-2980, https://doi.org/10.5194/amt-8-2961-2015, 2015.

Guerlet, S., Butz, A., Schepers, D., Basu, S., Hasekamp, O. P., Kuze, A., Yokota, T., Blavier, J.-F., Deutscher, N. M., Grif?th, D. W. T., Hase, F., Kyro, E., Morino, I., Sherlock, V., Sussmann, R., Galli, A., and Aben, I.: Impact of aerosols and thin cirrus on retrieving and validating $\mathrm{XCO}_{2}$ from GOSAT shortwave infrared measurements, J. Geophys. Res.-Atmos., 118, 4887-4905, https://doi.org/10.1002/jgrd.50332, 2013.

IPCC: Climate Change 2014: Synthesis Report, Contribution of Working Groups I, II and III to the Fifth Assessment Report of the Intergovernmental Panel on Climate Change, edited by: Core Writing Team, Pachauri, R. K., and Meyer, L. A., IPCC, Geneva, Switzerland, 151 pp., 2014.

Kiel, M., Wunch, D., Wennberg, P. O., Toon, G. C., Hase, F., and Blumenstock, T.: Improved retrieval of gas abundances from near-infrared solar FTIR spectra measured at the Karlsruhe TCCON station, Atmos. Meas. Tech., 9, 669-682, https://doi.org/10.5194/amt-9-669-2016, 2016a.

Kiel, M., Hase, F., Blumenstock, T., and Kirner, O.: Comparison of $\mathrm{XCO}$ abundances from the Total Carbon Column Observing Network and the Network for the Detection of Atmospheric Composition Change measured in Karlsruhe, Atmos. Meas. Tech., 9, 2223-2239, https://doi.org/10.5194/amt-9-2223-2016, 2016 b.

Kulawik, S., Wunch, D., O’Dell, C., Frankenberg, C., Reuter, M., Oda, T., Chevallier, F., Sherlock, V., Buchwitz, M., Osterman, G., Miller, C. E., Wennberg, P. O., Griffith, D., Morino, I., Dubey, M. K., Deutscher, N. M., Notholt, J., Hase, F., Warneke, T., Sussmann, R., Robinson, J., Strong, K., Schneider, M., De Mazière, M., Shiomi, K., Feist, D. G., Iraci, L. T., and Wolf, J.: Consistent evaluation of ACOS-GOSAT, BESD-SCIAMACHY, CarbonTracker, and MACC through comparisons to TCCON, Atmos. Meas. Tech., 9, 683-709, https://doi.org/10.5194/amt-9683-2016, 2016.

Kuze, A., Suto, H., Nakajima, M., and Hamazaki, T.: Thermal and near infrared sensor for carbon observation Fourier-transform spectrometer on the Greenhouse Gases Observing Satellite for greenhouse gases monitoring, Appl. Opt., 48, 6716-6733, 2009.

Le Quéré, C., Peters, G. P., Andres, R. J., Andrew, R. M., Boden, T. A., Ciais, P., Friedlingstein, P., Houghton, R. A., Mar- land, G., Moriarty, R., Sitch, S., Tans, P., Arneth, A., Arvanitis, A., Bakker, D. C. E., Bopp, L., Canadell, J. G., Chini, L. P., Doney, S. C., Harper, A., Harris, I., House, J. I., Jain, A. K., Jones, S. D., Kato, E., Keeling, R. F., Klein Goldewijk, K., Körtzinger, A., Koven, C., Lefèvre, N., Maignan, F., Omar, A., Ono, T., Park, G.-H., Pfeil, B., P oulter, B., Raupach, M. R., Regnier, P., Rödenbeck, C., Saito, S., Schwinger, J., Segschneider, J., Stocker, B. D., Takahashi, T., Tilbrook, B., van Heuven, S., Viovy, N., Wanninkhof, R., Wiltshire, A., and Zaehle, S.: Global carbon budget 2013, Earth Syst. Sci. Data, 6, 235-263, https://doi.org/10.5194/essd-6-235-2014, 2014.

Lindqvist, H., O'Dell, C. W., Basu, S., Boesch, H., Chevallier, F., Deutscher, N., Feng, L., Fisher, B., Hase, F., Inoue, M., Kivi, R., Morino, I., Palmer, P. I., Parker, R., Schneider, M., Sussmann, R., and Yoshida, Y.: Does GOSAT capture the true seasonal cycle of carbon dioxide?, Atmos. Chem. Phys., 15, 13023-13040, https://doi.org/10.5194/acp-15-13023-2015, 2015.

Liu, C., Beirle, S., Butler, T., Liu, J., Hoor, P., Jöckel, P., Penning de Vries, M., Pozzer, A., Frankenberg, C., Lawrence, M. G., Lelieveld, J., Platt, U., and Wagner, T.: Application of SCIAMACHY and MOPITT CO total column measurements to evaluate model results over biomass burning regions and Eastern China, Atmos. Chem. Phys., 11, 6083-6114, https://doi.org/10.5194/acp-11-6083-2011, 2011.

Messerschmidt, J., Macatangay, R., Notholt, J., Petri, C., Warneke T., and Weinzierl, C.: Side by side measurements of $\mathrm{CO}_{2}$ by ground-based Fourier transform spectrometry (FTS), Tellus B, 62, 749-758, https://doi.org/10.1111/j.1600-0889.2010.00491.x, 2010.

Messerschmidt, J., Geibel, M. C., Blumenstock, T., Chen, H., Deutscher, N. M., Engel, A., Feist, D. G., Gerbig, C., Gisi, M., Hase, F., Katrynski, K., Kolle, O., Lavric, J. V., Notholt, J., Palm, M., Ramonet, M., Rettinger, M., Schmidt, M., Sussmann, R., Toon, G. C., Truong, F., Warneke, T., Wennberg, P. O., Wunch, D., and Xueref-Remy, I.: Calibration of TCCON column-averaged $\mathrm{CO}_{2}$ : the first aircraft campaign over European TCCON sites, Atmos. Chem. Phys., 11, 10765-10777, https://doi.org/10.5194/acp-11-10765-2011, 2011.

Morino, I., Uchino, O., Inoue, M., Yoshida, Y., Yokota, T., Wennberg, P. O., Toon, G. C., Wunch, D., Roehl, C. M., Notholt, J., Warneke, T., Messerschmidt, J., Griffith, D. W. T., Deutscher, N. M., Sherlock, V., Connor, B., Robinson, J., Sussmann, R., and Rettinger, M.: Preliminary validation of column-averaged volume mixing ratios of carbon dioxide and methane retrieved from GOSAT short-wavelength infrared spectra, Atmos. Meas. Tech., 4, 1061-1076, https://doi.org/10.5194/amt-4-1061-2011, 2011.

Morino, I., Matsuzaki, T., and Shishime, A.: TCCON data from Tsukuba, Ibaraki, Japan, 125HR, Release GGG2014R1, TCCON data archive, hosted by CDIAC, https://doi.org/10.14291/tccon.ggg2014.tsukuba02.R1/1241486, 2014.

Newman, S., Jeong, S., Fischer, M. L., Xu, X., Haman, C. L., Lefer, B., Alvarez, S., Rappenglueck, B., Kort, E. A., Andrews, A. E., Peischl, J., Gurney, K. R., Miller, C. E., and Yung, Y. L.: Diurnal tracking of anthropogenic $\mathrm{CO}_{2}$ emissions in the Los Angeles basin megacity during spring 2010, Atmos. Chem. Phys., 13, 4359-4372, https://doi.org/10.5194/acp-13-4359-2013, 2013.

Nguyen, H., Osterman, G., Wunch, D., O’Dell, C., Mandrake, L., Wennberg, P., Fisher, B., and Castano, R.: A method for colocat- 
ing satellite $X_{\mathrm{CO}_{2}}$ data to ground-based data and its application to ACOS-GOSAT and TCCON, Atmos. Meas. Tech., 7, 26312644, https://doi.org/10.5194/amt-7-2631-2014, 2014.

Ohyama, H., Kawakami, S., Tanaka, T., Morino, I., Uchino, O., Inoue, M., Sakai, T., Nagai, T., Yamazaki, A., Uchiyama, A., Fukamachi, T., Sakashita, M., Kawasaki, T., Akaho, T., Arai, K., and Okumura, H.: Observations of $\mathrm{XCO}_{2}$ and $\mathrm{XCH}_{4}$ with ground-based high-resolution FTS at Saga, Japan, and comparisons with GOSAT products, Atmos. Meas. Tech., 8, 5263-5276, https://doi.org/10.5194/amt-8-5263-2015, 2015.

Olsen, S. C. and Randerson, J. T.: Differences between surface and column atmospheric $\mathrm{CO}_{2}$ and implications for carbon cycle research, J. Geophys. Res.-Atmos., 109, D02301, https://doi.org/10.1029/2003JD003968, 2004.

Reuter, M., Bovensmann, H., Buchwitz, M., Burrows, J. P., Connor, B. J., Deutscher, N. M., Griffith, D. W. T., Heymann,J., KeppelAleks, G., Messerschmidt, J., Notholt, J., Petri,C., Robinson, J., Schneising, O., Sherlock, V., Velazco, V., Warneke, T., Wennberg, P. O., and Wunch, D.: Retrieval of atmospheric $\mathrm{CO}_{2}$ with enhanced accuracy and precision from SCIAMACHY: Validation with FTS measurements and comparison with model results, J. Geophys. Res.-Atmos., 116, D04301, https://doi.org/10.1029/2010JD015047, 2011.

Rodgers, C. D. and Connor, B. J.: Intercomparison of remote sounding instruments, J. Geophys. Res.-Atmos., 108, 4116, https://doi.org/10.1029/2002JD002299, 2003.

Rokotyan, N. V., Zakharov, V. I., Gribanov, K. G., Schneider, M., Bréon, F.-M., Jouzel, J., Imasu, R., Werner, M., Butzin, M., Petri, C., Warneke, T., and Notholt, J.: A posteriori calculation of $\delta^{18} \mathrm{O}$ and $\delta \mathrm{D}$ in atmospheric water vapour from ground-based nearinfrared FTIR retrievals of $\mathrm{H}_{2}^{16} \mathrm{O}, \mathrm{H}_{2}^{18} \mathrm{O}$, and $\mathrm{HD}^{16} \mathrm{O}$, Atmos. Meas. Tech., 7, 2567-2580, https://doi.org/10.5194/amt-7-25672014, 2014.

Rokotyan, N. V., Imasu, R., Zakharov, V. I., Gribanov, K. G., and Khamatnurova, M. Y.: The amplitude of the $\mathrm{CO}_{2}$ seasonal cycle in the atmosphere of the Ural region retrieved from ground-based and satellite near-IR measurements, Atmos. Ocean Opt. 28, 4955, https://doi.org/10.1134/S102485601501011X, 2015.

Sarangi, T., Naja, M., Ojha, N., Kumar, R., Lal, S., Venkataramani, S., Kumar, A., Sagar, R., and Chandola, H. C.: First simultaneous measurements of ozone, CO, and NOy at a high-altitude regional representative site in the central Himalayas, J. Geophys. Res.-Atmos. 119, 1592-1611, https://doi.org/10.1002/2013JD020631, 2014.

Schibig, M. F., Steinbacher, M., Buchmann, B., van der LaanLuijkx, I. T., van der Laan, S., Ranjan, S., and Leuenberger, M. C.: Comparison of continuous in situ $\mathrm{CO}_{2}$ observations at Jungfraujoch using two different measurement techniques, Atmos. Meas. Tech., 8, 57-68, https://doi.org/10.5194/amt-8-572015, 2015.

Schneising, O., Bergamaschi, P., Bovensmann, H., Buchwitz, M., Burrows, J. P., Deutscher, N. M., Griffith, D. W. T., Heymann, J., Macatangay, R., Messerschmidt, J., Notholt, J., Rettinger, M., Reuter, M., Sussmann, R., Velazco, V. A., Warneke, T., Wennberg, P. O., and Wunch, D.: Atmospheric greenhouse gases retrieved from SCIAMACHY: comparison to ground-based FTS measurements and model results, Atmos. Chem. Phys., 12, 1527-1540, https://doi.org/10.5194/acp-12-1527-2012, 2012.
Schneising, O., Reuter, M., Buchwitz, M., Heymann, J., Bovensmann, H., Burrows, J. P.: Terrestrial carbon sink observed from space: variation of growth rates and seasonal cycle amplitudes in response to interannual surface temperature variability, Atmos. Chem. Phys. 14, 133-141, https://doi.org/10.5194/acp-14-1332014, 2014.

Suntharalingam, P., Jacob, D. J., Palmer, P. I., Logan, J. A., Yantosca, R. M., Xiao, Y. P., Evans, M. J., Streets, D. G., Vay, S. L., and Sachse, G. W.: Improved quantification of Chinese carbon fluxes using $\mathrm{CO}_{2} / \mathrm{CO}$ correlations in Asian outflow, J. Geophys.Res.-Atmos., 109, D18S18, https://doi.org/10.1029/2003JD004362, 2004.

Tian, Y., Sun, Y., Liu, C., Wang, W., Shan, C., Xu, X., and Hu, Q.: Characterization of methane variability from near infrared solar spectra in Hefei, China, in preparation, 2017.

Toon, G., Blavier, J.-F., Washenfelder, R., Wunch, D., KeppelAleks, G., Wennberg, P., Connor, B., Sherlock, V., Griffith, D., Deutscher, N., and Notholt, J.: Total Column Carbon Observing Network (TCCON), Advances in Imaging, Opt. Soc. Am., Vancouver, p. JMA3, https://doi.org/10.1364/FTS.2009.JMA3, 2009.

Vardag, S. N., Hammer, S., O’Doherty, S., Spain, T. G., Wastine, B., Jordan, A., and Levin, I.: Comparisons of continuous atmospheric $\mathrm{CH}_{4}, \mathrm{CO}_{2}$ and $\mathrm{N}_{2} \mathrm{O}$ measurements - results from a travelling instrument campaign at Mace Head, Atmos. Chem. Phys., 14, 8403-8418, https://doi.org/10.5194/acp-148403-2014, 2014.

Wang, Y., Munger, J. W., Xu, S., McElroy, M. B., Hao, J., Nielsen, C. P., and Ma, H.: $\mathrm{CO}_{2}$ and its correlation with $\mathrm{CO}$ at a rural site near Beijing: implications for combustion efficiency in China, Atmos. Chem. Phys., 10, 8881-8897, https://doi.org/10.5194/acp-10-8881-2010, 2010.

Wang, Z., Deutscher, N. M., Warneke, T., Notholt, J., Dils, B., Griffith, D. W. T., Schmidt, M., Ramonet, M., and Gerbig, C.: Retrieval of tropospheric column-averaged $\mathrm{CH}_{4}$ mole fraction by solar absorption FTIR-spectrometry using $\mathrm{N}_{2} \mathrm{O}$ as a proxy, Atmos. Meas. Tech., 7, 3295-3305, https://doi.org/10.5194/amt-73295-2014, 2014.

Washenfelder, R. A., Toon, G. C., Blavier, J.-F., Yang, Z., Allen,N. T., Wennberg, P. O., Vay, S. A., Matross, D. M., and Daube, B. C.: Carbon dioxide column abundances at the Wisconsin Tall Tower site, J. Geophys. Res.-Atmos., 111, D22305, https://doi.org/10.1029/2006JD007154, 2006.

WMO: 17th WMO/IAEA Meeting on Carbon Dioxide, Other Greenhouse Gases and Related Tracers Measurement Techniques (GGMT-2013), Beijing, China, 10-13 June 2013, GAW Report No. 213, World Meteorological Organization, 30 Geneva, Switzerland, 2014.

Wunch, D., Wennberg, P. O., Toon, G. C., Keppel-Aleks, G., and Yavin, Y. G.: Emissions of greenhouse gases from a North American megacity, Geophys. Res. Lett., 36, L15810, https://doi.org/10.1029/2009GL039825, 2009.

Wunch, D., Toon, G. C., Wennberg, P. O., Wofsy, S. C., Stephens, B. B., Fischer, M. L., Uchino, O., Abshire, J. B., Bernath, P., Biraud, S. C., Blavier, J.-F. L., Boone, C., Bowman, K. P., Browell, E. V., Campos, T., Connor, B. J., Daube, B. C., Deutscher, N. M., Diao, M., Elkins, J. W., Gerbig, C., Gottlieb, E., Griffith, D. W. T., Hurst, D. F., Jiménez, R., Keppel-Aleks, G., Kort, E. A., Macatangay, R., Machida, T., Matsueda, H., Moore, F., 
Morino, I., Park, S., Robinson, J., Roehl, C. M., Sawa, Y., Sherlock, V., Sweeney, C., Tanaka, T., and Zondlo, M. A.: Calibration of the Total Carbon Column Observing Network using aircraft profile data, Atmos. Meas. Tech., 3, 1351-1362, https://doi.org/10.5194/amt-3-1351-2010, 2010.

Wunch, D., Toon, G. C., Blavier, J.-F. L., Washenfelder, R. A., Notholt, J., Connor, B. J., Griffith, D. W. T., Sherlock, V., and Wennberg, P. O.: The Total Carbon Column Observing Network, Philos. T. Roy. Soc. A, 369, 2087-2112, https://doi.org/10.1098/rsta.2010.0240, 2011a.

Wunch, D., Wennberg, P. O., Toon, G. C., Connor, B. J., Fisher, B., Osterman, G. B., Frankenberg, C., Mandrake, L., O’Dell, C., Ahonen, P., Biraud, S. C., Castano, R., Cressie, N., Crisp, D., Deutscher, N. M., Eldering, A., Fisher, M. L., Griffith, D. W. T., Gunson, M., Heikkinen, P., Keppel-Aleks, G., Kyrö, E., Lindenmaier, R., Macatangay, R., Mendonca, J., Messerschmidt, J., Miller, C. E., Morino, I., Notholt, J., Oyafuso, F. A., Rettinger, M., Robinson, J., Roehl, C. M., Salawitch, R. J., Sherlock, V., Strong, K., Sussmann, R., Tanaka, T., Thompson, D. R., Uchino, O., Warneke, T., and Wofsy, S. C.: A method for evaluating bias in global measurements of $\mathrm{CO}_{2}$ total columns from space, Atmos. Chem. Phys., 11, 12317-12337, https://doi.org/10.5194/acp-11-12317-2011, 2011 b.

Wunch, D., Toon, G. C., Sherlock, V., Deutscher, N. M, Liu, X., Feist, D. G., and Wennberg, P. O.: The Total Carbon Column Observing Network's GGG2014 Data Version, Carbon Dioxide Information Analysis Center, Oak Ridge National Laboratory, Oak Ridge, Tennessee, USA, https://doi.org/10.14291/tccon.ggg2014.documentation.R0/1221662, 2015.

Wunch, D., Wennberg, P. O., Osterman, G., Fisher, B., Naylor, B., Roehl, C. M., O’Dell, C., Mandrake, L., Viatte, C., Kiel, M., Griffith, D. W. T., Deutscher, N. M., Velazco, V. A., Notholt, J., Warneke, T., Petri, C., De Maziere, M., Sha, M. K., Sussmann, R., Rettinger, M., Pollard, D., Robinson, J., Morino, I., Uchino, O., Hase, F., Blumenstock, T., Feist, D. G., Arnold, S. G., Strong, K., Mendonca, J., Kivi, R., Heikkinen, P., Iraci, L., Podolske, J., Hillyard, P. W., Kawakami, S., Dubey, M. K., Parker, H. A., Sepulveda, E., García, O. E., Te, Y., Jeseck, P., Gunson, M. R., Crisp, D., and Eldering, A.: Comparisons of the Orbiting Carbon Observatory-2 (OCO-2) $X_{\mathrm{CO}_{2}}$ measurements with TCCON, Atmos. Meas. Tech., 10, 2209-2238, https://doi.org/10.5194/amt10-2209-2017, 2017.
Yang, Z., Toon, G. C., Margolis, J. S., and Wennberg, P. O.: Atmospheric $\mathrm{CO}_{2}$ retrieved from ground-based near IR solar spectra, Geophys. Res. Lett., 29, 53-51-53-54, https://doi.org/10.1029/2001GL014537, 2002.

Yang, Z., Wennberg, P. O., Cageao, R. P., Pongetti, T. J., Toon, G. C., and Sander, S. P.: Ground-based photon path measurements from solar absorption spectra of the $\mathrm{O}_{2}$ A-band, J. Quant. Spectrosc. Ra., 90, 309-321, https://doi.org/10.1016/j.jqsrt.2004.03.020, 2005.

Yin, Y., Chevallier, F., Ciais, P., Broquet, G., Fortems-Cheiney, A., Pison, I., and Saunois, M.: Decadal trends in global CO emissions as seen by MOPITT. Atmos. Chem. Phys. 15, 1343313451, https://doi.org/10.5194/acp-15-13433-2015, 2015.

Yoshida, Y., Kikuchi, N., Morino, I., Uchino, O., Oshchepkov, S.,Bril, A., Saeki, T., Schutgens, N., Toon, G. C.,Wunch, D., Roehl, C. M., Wennberg, P. O., Griffith, D. W. T., Deutscher, N. M., Warneke, T., Notholt, J., Robinson, J., Sherlock, V., Connor, B., Rettinger, M., Sussmann, R., Ahonen, P., Heikkinen, P., Kyrö, E., Mendonca, J., Strong, K., Hase, F., Dohe, S., and Yokota, T.: Improvement of the retrieval algorithm for GOSAT SWIR $\mathrm{XCO}_{2}$ and $\mathrm{XCH}_{4}$ and their validation using TCCON data, Atmos. Meas. Tech., 6, 1533-1547, https://doi.org/10.5194/amt-61533-2013, 2013.

Zhou, M., Dils, B., Wang, P., Detmers, R., Yoshida, Y., O’Dell, C. W., Feist, D. G., Velazco, V. A., Schneider, M., and Maziere, M. De, Validation of TANSO-FTS/GOSAT $\mathrm{XCO}_{2}$ and $\mathrm{XCH}_{4}$ glint mode retrievals using TCCON data from near-ocean sites, Atmos. Meas. Tech., 9, 1415-1430, https://doi.org/10.5194/amt-91415-2016, 2016. 